\title{
ENVIRONMENTAL BARRIER COATINGS FOR THE ENERGY EFFICIENT HEAT ENGINES PROGRAM
}

\author{
FINAL REPORT
}

For work performed from

June 1, 2001 to October 31, 2004

Work Performed Under

Cooperative Agreement No. DE-FC36-01CH1 1086

Prepared for

United States Department of Energy

by

Katherine T. Faber, Principal Investigator

Northwestern University

\section{January 31, 2005}

\section{NOTICE}

This report was prepared as an account of work sponsored by the United States Government. Neither the United States Government nor the Department of Energy, nor any of their employees, not any of their contractors, subcontractors, or their employees, make any warranty, express or implied, or assumes any legal liability or responsibility for the accuracy, completeness, or usefulness of any information, apparatus, project or process disclosed or represents that issue would not infringe privately-owned rights. 


\section{DISCLAIMER}

This report was prepared as an account of work sponsored by an agency of the United States Government. Neither the United States Government nor any agency thereof, nor any of their employees, makes any warranty, express or implied, or assumes any legal liability or responsibility for the accuracy, completeness, or usefulness of any information, apparatus, product, or process disclosed, or represents that its use would not infringe privately owned rights. Reference herein to any specific commercial product, process, or service by trade name, trademark, manufacturer, or otherwise does not necessarily constitute or imply its endorsement, recommendation, or favoring by the United States Government or any agency thereof. The views and opinions of authors expressed herein do not necessarily state or reflect those of the United States Government or any agency thereof. 


\begin{abstract}
This program aimed to develop a fundamental understanding of the microstructural, mechanical, and chemical properties of $\mathrm{Ta}_{2} \mathrm{O}_{5}$-based coatings for $\mathrm{Si}_{3} \mathrm{~N}_{4}$ (AS800) substrates and optimize such coatings for environmental barriers. The program consisted of three tasks: processing of $\mathrm{Ta}_{2} \mathrm{O}_{5}$ coatings, phase and microstructural development, and life-limiting phenomena. Northwestern University formed a cross-functional team with Lehigh University, Honeywell Inc., and Oak Ridge National Laboratory.
\end{abstract}

The major accomplishments are:

- Conditions for the plasma spray of $\mathrm{Ta}_{2} \mathrm{O}_{5}$ and its alloys were optimized to provide maximum density and thickness.

- Adherent small particle plasma spray coatings of $\mathrm{Ta}_{2} \mathrm{O}_{5}$ can be routinely prepared.

- $\mathrm{Ta}_{2} \mathrm{O}_{5}$ can be stabilized against its disruptive phase transformation to $1400^{\circ} \mathrm{C}$ by the addition of one or more oxides of $\mathrm{Al}, \mathrm{La}$, and/or $\mathrm{Nb}$.

- Residual stresses in the $\mathrm{Ta}_{2} \mathrm{O}_{5}$ coatings were measured using X-rays and changed with thermal exposure.

- Properly doped coatings are more resistant against thermal cycling than undoped coatings, and can be cycled many thousand times without spallation.

- Water vapor testing in the ORNL Keiser Rig of adherent coatings showed that undoped $\mathrm{Ta}_{2} \mathrm{O}_{5}$ is not an effective barrier at preventing chemical changes to the AS800.

- Limited water vapor testing of doped and adherent coatings, which had successfully survived many thermal cycles, showed that in the water vapor environment, de-cohesion may occur. 


\section{PROJECT SUMMARY}

Development of environmental barrier coatings (EBC) for the protection of silicon-based ceramics designed for use in gas turbine engines has been ongoing for over a decade. EBCs serve to shield the ceramic components from harmful gas turbine environment species, such as water vapor, which volatilize the protective silica layer that forms on silicon carbide and silicon nitride. Without protection, silicon-based ceramic components have exhibited severe surface recession which compromises their long-term use in gas turbines.

An effective EBC must prevent recession and degradation while not compromising the mechanical properties of the ceramic component over the desired lifetime. The coating material must be resistant to the gas turbine environment and must adhere well to the ceramic component. In addition, it should minimize harmful species from reaching the underlying ceramic, and/or prevent the volatilization product from leaving the surface of the substrate. Diffusion through the coating or exposure of the gas turbine environment to the ceramic through open porosity or cracking should be prevented. Macro-stresses, which could be a result of coefficient of thermal expansion mismatch with the substrate, and micro-stresses, which could result in materials with anisotropic coefficient of thermal expansions, should be minimized to prevent cracks in the coating.

The goal of this program was to develop a fundamental understanding of the microstructural, mechanical, and chemical properties of $\mathrm{Ta}_{2} \mathrm{O}_{5}$-based coatings for $\mathrm{Si}_{3} \mathrm{~N}_{4}$ substrates and optimize such coatings for environmental barriers. The program consisted of three tasks

Task 1: Processing of $\mathrm{Ta}_{2} \mathrm{O}_{5}$ coatings

Task 2: Phase and microstructural development

Task 3: Life limiting phenomena Northwestern University formed a cross-functional team for this environmental barrier coating research. Team members consisted of Lehigh University, a leader in research on microstructure and mass transport in ceramics, and Honeywell Inc., an industrial leader in ceramic and coating research and development and a supplier of silicon nitride ceramic engine components. Related studies at high temperatures and water vapor pressures were conducted at Oak Ridge National Laboratory, but are reported in an independent document. Northwestern University, Honeywell, Inc. and Lehigh University participants are listed in Appendix A.

The efforts undertaken and results obtained in each of the above tasks will be discussed in the following sections. Publications and presentations of this work are listed in Appendix B.

\section{Task 1: Processing of $\mathrm{Ta}_{2} \mathrm{O}_{5}$ coatings}

Honeywell supplied Northwestern with process information, AS800 specimens, and prereacted $\mathrm{Ta}_{2} \mathrm{O}_{5}$ alloy powders. Process information relating to Honeywell's experience with applying plasma sprayed $\mathrm{Ta}_{2} \mathrm{O}_{5}$ to $\mathrm{AS} 800$ was transferred to Northwestern, including information regarding preferred substrate temperature conditions and their experience with particle sizes and the pre-reaction of powder. 
Approximately 150 coupons with one surface as-processed were cut from AS800 billets. Several sample geometries were prepared to accommodate both Tasks 1 and 3 . In the latter, substrates were prepared for (a) thermal cycling at Honeywell, (b) Keiser rig testing at ORNL, and (c) burner rig testing at IKTS (Fraunhofer Institute for Keramic Technology and Sintering, Dresden, Germany). However, burner rig coupons were prepared, but not tested. Most specimens were heat treated at $1250^{\circ} \mathrm{C}$ for $0.5 \mathrm{~h}$ in air to stabilize the grain boundary oxynitride phase against the possibility of a disruptive volume expansion during exposure to the intermediate temperatures which the samples were subjected to during plasma spraying ${ }^{1}$. However early samples were not given this treatment and the low strengths noted for those samples as part of the Keiser Rig tests at ORNL may have been as a result of damage to changes in the un-stabilized AS800 grain boundary phases during SPPS.

Using a D-optimal design of experiments, small particle plasma-sprayed (SPPS) processing variables were optimized to maximize coating density. It was anticipated that the maximum density would minimize permeability of water vapor in use. The effect of processing variable on coating thickness was also determined as an indication of spray efficiency. For pure $\mathrm{Ta}_{2} \mathrm{O}_{5}$ powders, a multiple regression model for coating porosity $(\mathrm{P})$ was found to be:

$$
\frac{1}{P}=-0.340+1.49 \times 10^{-3} R-2.40 \times 10^{-6} R^{2}+0.0217 A+0.0950 O-4.33 \times 10^{-3}(A * O)
$$

where $\mathrm{R}$ is robot scan rate, $\mathrm{A}$ is injector angle and $\mathrm{O}$ is injector offset. Note the interaction effects between angle and offset $\left(\mathrm{A}^{*} \mathrm{O}\right)$. Plasma-spray conditions for coatings optimized for thickness are shown in Table 1 . The predicted means for thickness and porosity computed from these models are 100 microns and $2.70 \%$, and the $95 \%$ confidence intervals for the means are 90 to $113 \mu \mathrm{m}$ for thickness and $2.24 \%$ and $3.41 \%$ for porosity.

Table 1. Spraying conditions for $\mathrm{Ta}_{2} \mathrm{O}_{5}$ coatings optimized for minimal porosity.

\begin{tabular}{|l|l|}
\hline Robot scan rate (R) & $315 \mathrm{~mm} / \mathrm{min}$ \\
\hline Injector angle (A) & $0^{\circ}$ \\
\hline Injector offset (O) & $5 \mathrm{~mm}$ \\
\hline Carrier gas flow (CF) & $3 \mathrm{slm}$ \\
\hline Power feeder disc speed (DS) & $0.4 \mathrm{rpm}$ \\
\hline Plasma gun power (P) & $40 \mathrm{~kW}$ \\
\hline Total gas flow (TF) & $44 \mathrm{slm}$ \\
\hline$\%$ Hydrogen in plasma gas $(\% \mathrm{H})$ & $25 \%$ \\
\hline
\end{tabular}

\footnotetext{
${ }^{1}$ In the intermediate temperature range $(\sim 700-1000 \mathrm{C})$, the microstructure is too rigid to allow the stress induced by the oxidation of oxinitride grain boundary phases to be relieved through viscous/plastic flow. This can result in cracking of the material under certain circumstances. For further discussion of this mechanism see, e.g., Patel, J.K., et al., "The low temperature oxidation problem in yttria-densified silicon nitride ceramics", Br. Ceram Trans. J. 87, 70-73, 1988.
} 
Several confirmation runs were completed at the settings shown in Table 1, with results that closely match the values of porosity predicted by the above equation. The average porosity for seven specimens was $2.76 \%$, with a $95 \%$ confidence interval for the mean of $1.7 \%$ to $3.8 \%$. The one-sided t-test shows that one cannot reject the null hypothesis ( $m e a n=2.70 \%, \mathrm{P}=0.90$ ). Figure 1 shows an optimized coating that has an average thickness of $85 \mu \mathrm{m}$ and approximate porosity of $1.5 \%$ (the smallest value found), as measured by stereological methods.

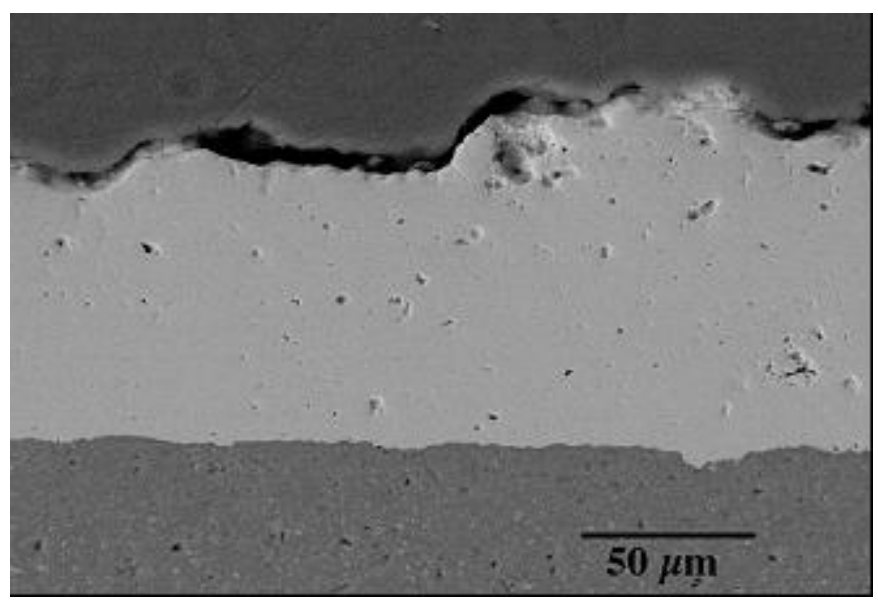

Figure 1. Scanning electron micrograph of optimized $\mathrm{Ta}_{2} \mathrm{O}_{5}$ of appropriate thickness.

\subsection{Preparation of $\mathrm{Ta}_{2} \mathrm{O}_{5}$ alloyed coatings}

Because of the important role of $\mathrm{Al}_{2} \mathrm{O}_{3}$ and $\mathrm{AlTaO}_{4}$ in grain boundary pinning of $\mathrm{Ta}_{2} \mathrm{O}_{5}$ described under Task 2, Honeywell investigated routes to prepare the following compositions:

- Pure $\mathrm{AlTaO}_{4}$ phase (1Al:1Ta) that could be used for mixing with pure $\mathrm{Ta}_{2} \mathrm{O}_{5}$ and with $\mathrm{Ta}_{2} \mathrm{O}_{5}+1 \mathrm{wt} \% \mathrm{Al}_{2} \mathrm{O}_{3}$ for plasma spray trials.

- $\mathrm{Ta}_{2} \mathrm{O}_{5}+3 \mathrm{wt} \% \mathrm{Al}_{2} \mathrm{O}_{3}$ (above expected solubility limit of $\mathrm{Al}$ in $\left.\mathrm{Ta}_{2} \mathrm{O}_{5}\right)\left(\mathrm{AlTaO}_{4}\right.$ formed during heat treatment) that could be used directly for plasma spray trials.

- $\mathrm{Ta}_{2} \mathrm{O}_{5}+2 \mathrm{wt} \% \mathrm{Al}_{2} \mathrm{O}_{3}$ (just above expected solubility limit of $\mathrm{Al}$ in $\mathrm{Ta}_{2} \mathrm{O}_{5}$ ) (trace $\mathrm{AlTaO}_{4}$ formed during heat treatment) that could be used directly for plasma spray trials.

- $\mathrm{Ta}_{2} \mathrm{O}_{5}+1 \mathrm{wt} \% \mathrm{Al}_{2} \mathrm{O}_{3}$ (just below expected solubility limit of $\mathrm{Al}$ in $\mathrm{Ta}_{2} \mathrm{O}_{5}$ that could be used directly for plasma spray trials or for mixing with pure $\mathrm{AlTaO}_{4}$ for plasma spray trials.

Mixtures of $\mathrm{Ta}_{2} \mathrm{O}_{5}$ (First Reaction, Inc) with appropriate amounts of either aluminum nitrate or gamma $(\gamma)$ alumina as the aluminum source, and heat-treated the mixtures in air at various temperatures $\left(5 \mathrm{hrs}\right.$ at temp, $10^{\circ} \mathrm{C} / \mathrm{min}$ heating/cooling rates).

X-ray diffraction analysis shows varying degrees of reaction depending on the temperature and source of alumina. The degree of reaction was assessed by evaluating the areas beneath the strongest peaks for $\beta-\mathrm{Ta}_{2} \mathrm{O}_{5}$ (JCPDS\# 25-0922) and $\mathrm{AlTaO}_{4}$ (JCPDS\# 25-1490). 
Equal weight was given to both phases in this evaluation. The percentage $\mathrm{AlTaO}_{4}$ was evaluated as follows:

$$
\% \mathrm{AlTaO}_{4}=\text { Area } \mathrm{AlTaO}_{4} /\left(\text { Area } \mathrm{AlTaO}_{4}+\text { Area } \beta-\mathrm{Ta}_{2} \mathrm{O}_{5}\right) * 100
$$

Tables 2 and 3 summarize the $\% \mathrm{AlTaO}_{4}$ seen in the mixtures that were heat-treated at varying temperatures. Table 2 shows a summary for heat treatments made using aluminum from aluminum nitrate. Table 3 shows a summary for heat treatments made using aluminum from $\gamma$ alumina.

Table 2: Summary of the $\% \mathrm{AlTaO}_{4}$ content (as determined by ratios of the areas beneath the strongest $\mathrm{AlTaO}_{4}$ and $\beta-\mathrm{Ta}_{2} \mathrm{O}_{5}$ XRD peaks) in $\mathrm{Ta}_{2} \mathrm{O}_{5}$-aluminum nitrate mixtures which were heat-treated at varying temperatures.

\begin{tabular}{|c|c|c|c|c|}
\hline $\begin{array}{c}\text { Temp } \\
\left({ }^{\circ} \mathbf{C}\right)\end{array}$ & 1Al:1Ta & $\mathbf{3} \mathbf{w t} \% \mathbf{A l}$ & $\mathbf{2} \mathbf{~ w t} \% \mathbf{A l}$ & $\mathbf{1} \mathbf{~ w t} \% \mathbf{A l}$ \\
\hline $\mathbf{1 2 0 0}$ & 44 & 6 & 2 & 0 \\
\hline $\mathbf{1 3 0 0}$ & 76 & 8 & 6 & 6 \\
\hline $\mathbf{1 3 5 0}$ & 91 & 17 & 4 & 0 \\
\hline $\mathbf{1 4 0 0}$ & 95 & 12 & 4 & 2 \\
\hline $\mathbf{1 5 0 0}$ & 81 & 10 & 8 & 0 \\
\hline
\end{tabular}

Table 3: Summary of the $\% \mathrm{AlTaO}_{4}$ content (as determined by ratios of the areas beneath the strongest $\mathrm{AlTaO}_{4}$ and $\beta-\mathrm{Ta}_{2} \mathrm{O}_{5}$ XRD peaks) in $\mathrm{Ta}_{2} \mathrm{O}_{5}-\gamma-\mathrm{Al}_{2} \mathrm{O}_{3}$ mixtures which were heat-treated at varying temperatures.

\begin{tabular}{|c|c|c|c|c|}
\hline $\begin{array}{c}\text { Temp } \\
\left({ }^{\circ} \mathbf{C}\right)\end{array}$ & 1Al:1Ta & $\mathbf{3} \mathbf{w t} \% \mathbf{A l}$ & $\mathbf{2} \mathbf{w t} \% \mathbf{A l}$ & $\mathbf{1} \mathbf{~ w t} \% \mathbf{A l}$ \\
\hline $\mathbf{1 2 0 0}$ & 24 & 2 & 1 & 0 \\
\hline $\mathbf{1 3 0 0}$ & 32 & 5 & 1 & 0 \\
\hline $\mathbf{1 3 5 0}$ & 45 & 7 & 3 & 0 \\
\hline $\mathbf{1 4 0 0}$ & 60 & 7 & 3 & 0 \\
\hline
\end{tabular}

Initial examination of the results indicate that nearly-pure $\mathrm{AlTaO}_{4}$ can be formed by the proper heat treatment of $\mathrm{Ta}_{2} \mathrm{O}_{5}$ and aluminum nitrate mixtures (1 Al: 1Ta) (for example at $1400^{\circ} \mathrm{C}$ ). A lesser degree of conversion at a given temperature was seen in the $\gamma-\mathrm{Al}_{2} \mathrm{O}_{3}$ mixtures. The reason for the decrease in the $\mathrm{AlTaO}_{4}: \beta-\mathrm{Ta}_{2} \mathrm{O}_{5}$ ratio at $1500^{\circ} \mathrm{C}$ in the nitrate mixtures is uncertain.

For the 1, 2, and $3 \mathrm{wt} \%$ mixtures, suitable heat treatment conditions were determined for preparing "pre-reacted" powders for plasma spraying, in which the $\beta-\mathrm{Ta}_{2} \mathrm{O}_{5}$ phase was saturated with aluminum. The results generally confirm the results reported earlier by Lehigh (Quarterly Report 4) that aluminum additions up to $1 \mathrm{wt} \%$ are held in $\mathrm{Ta}_{2} \mathrm{O}_{5}-\mathrm{Al}$ solid solution and that by 3 $\mathrm{wt} \% \mathrm{AlTaO}_{4}$ significant precipitation can be seen. In addition, these results indicate that the 
$\mathrm{AlTaO}_{4}$ formation occurs to a limited extent for $2 \mathrm{wt} \% \mathrm{Al}$ additions. The results for the $1 \mathrm{wt} \%$ nitrate additions also suggest that under certain conditions $\mathrm{AlTaO}_{4}$ may be seen in the $1 \%$ mixtures, although due to difficulties encountered with nitrate processing, that observation should be further examined.

In addition to the powders described above, Honeywell also supplied Northwestern with the following pre-reacted powders for plasma spraying:

- $\mathrm{Ta}_{2} \mathrm{O}_{5}$ with $5 \mathrm{wt} \% \mathrm{Al}_{2} \mathrm{O}_{3}\left(1400^{\circ} \mathrm{C} / 5\right.$ hour in air) (prepared by Honeywell under earlier internal efforts)

- $\mathrm{Ta}_{2} \mathrm{O}_{5}$ with $3 \mathrm{wt} \% \mathrm{Al}_{2} \mathrm{O}_{3}+3 \mathrm{wt} \% \mathrm{La}_{2} \mathrm{O}_{3}\left(1400^{\circ} \mathrm{C} / 5\right.$ hour in air) (prepared by Honeywell under internal efforts)

- $\mathrm{Ta}_{2} \mathrm{O}_{5}+1.5 \mathrm{wt} \% \mathrm{Al}_{2} \mathrm{O}_{3}$

- $\mathrm{Ta}_{2} \mathrm{O}_{5}+1.5 \mathrm{wt} \% \mathrm{Al}_{2} \mathrm{O}_{3}+1.5 \mathrm{wt} \% \mathrm{La}_{2} \mathrm{O}_{3}$

The latter two powders were made by milling high purity oxides (First Reaction, BaikowskiGamma type, and American Elements, respectively) in alcohol, evaporating the alcohol, and calcining the mixture at $1350^{\circ} \mathrm{C}$ for $5 \mathrm{hrs}\left(5^{\circ} \mathrm{C} /\right.$ minute heating rate $)$.

Plasma spray parameters for alloyed powders were identical to those used on pure $\mathrm{Ta}_{2} \mathrm{O}_{5}$ and were previously optimized. The substrates $(5 \mathrm{~cm} \times 2.5 \mathrm{~cm} \times 0.3 \mathrm{~cm})$ were ultrasonically cleaned in propanol for 5 minutes prior to spraying. The substrate was held against a ceramic plate containing heating elements which preheated the AS800 prior to plasma spraying. Samples prepared under this effort were used for static heat treatments, thermal cycling, Keiser Rig experiments and residual stress measurements.

\section{Task 2: Phase and Microstructural Development}

This task was to identify appropriate dopants and/or second phases which would enhance the effectiveness of $\mathrm{Ta}_{2} \mathrm{O}_{5}$ as an environmental barrier coating, in terms of microstructural stability, inhibition of grain boundary transport kinetics, stabilization of the $\beta-\mathrm{Ta}_{2} \mathrm{O}_{5}$ phase to higher temperatures and improved thermal expansion match with the $\mathrm{Si}_{3} \mathrm{~N}_{4}$ substrate. A large portion of the effort focused on the influence of dopants of $\mathrm{Al}_{2} \mathrm{O}_{3}, \mathrm{La}_{2} \mathrm{O}_{3}$, and $\mathrm{Nb}_{2} \mathrm{O}_{5}$. This work was largely conducted by investigators at Lehigh University identified in Appendix A.

Samples for these studies were prepared as pellets using conventional ceramic powder mixing, pressing and sintering techniques. Results from these studies were often incorporated into powder processing strategies at Honeywell and were plasma-sprayed at Northwesten University for further testing.

\subsection{Phase transformation from orthorhombic $(\beta)$ to tetragonal $(\alpha) \mathrm{Ta}_{2} \mathrm{O}_{5}$}

It was observed that for undoped $\mathrm{Ta}_{2} \mathrm{O}_{5}$, extensive cracking of the pellets occurred during sintering due to the volume expansion associated with the transformation from the orthorhombic $(\beta)$ to tetragonal $(\alpha)$ phase. We have estimated the magnitude of the volume expansion to be of the order of 6.2 to $8.6 \%$. High temperature in-situ X-ray diffraction studies were carried out at Alfred University to further study the transformation. Diffraction patterns of undoped $\mathrm{Ta}_{2} \mathrm{O}_{5}$ 
during heating and cooling are given in Figure 2. The number by each individual pattern represents the temperature at which the X-ray scan was carried out; the letter "d" indicates cooling down. It can be seen that from room temperature $\left(50^{\circ} \mathrm{C}\right)$ up to $1100^{\circ} \mathrm{C}$, the patterns correspond to the orthorhombic $(\beta)$ phase. At $1300^{\circ} \mathrm{C}$, however, a new peak emerged at twotheta $\sim 36.57^{\circ}$ (indicated by an arrow), which is the strongest distinguishable peak for the tetragonal $(\alpha)$ phase. This indicates the occurrence of the phase transformation from $\beta$-to- $\alpha$.

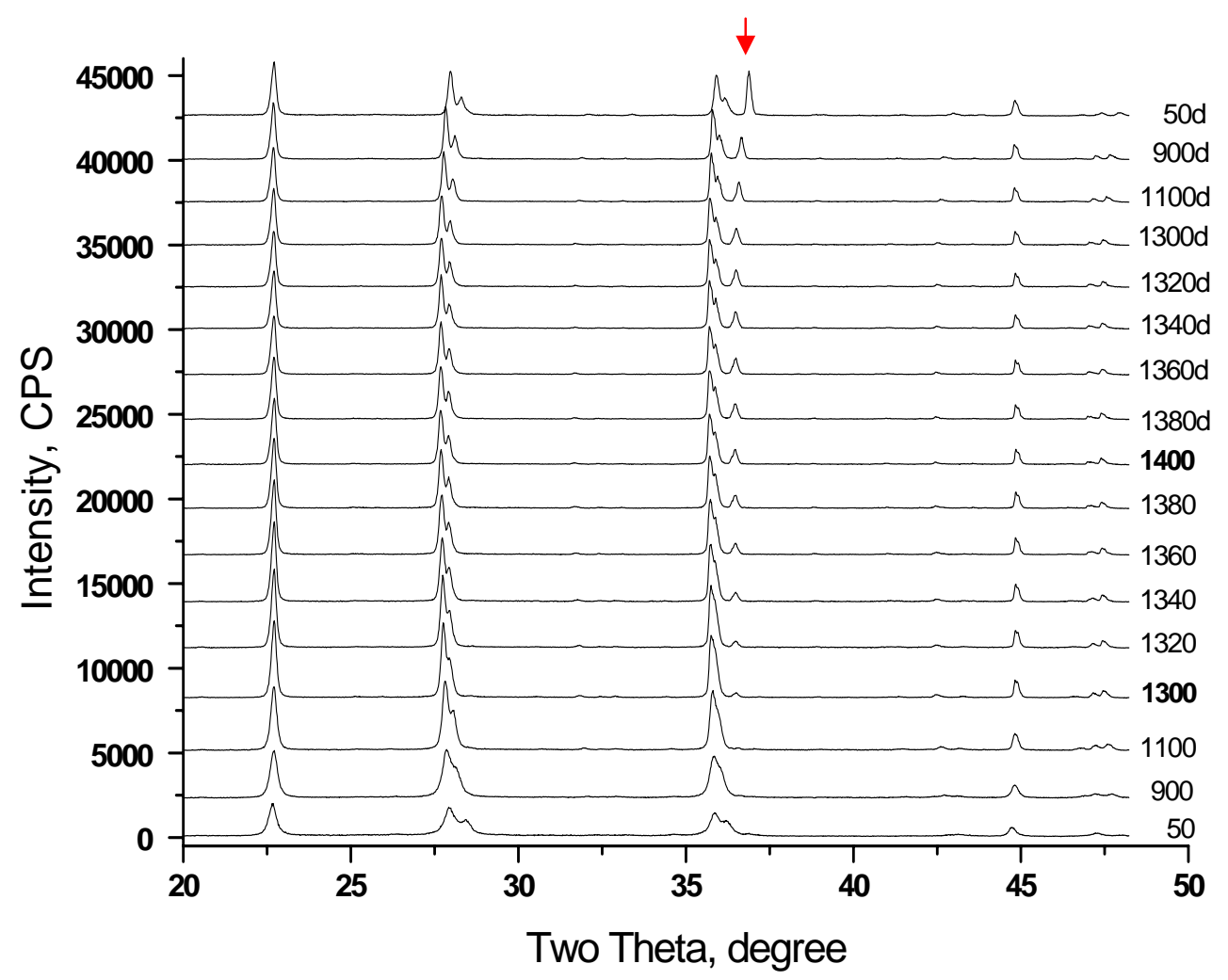

Figure 2. X-ray diffraction patterns of an undoped $\mathrm{Ta}_{2} \mathrm{O}_{5}$ powder, as milled. The arrow indicates the position of a peak associated with the formation of the tetragonal phase.

The magnitude of the $\alpha$-peak grew as the temperature increased, showing an increase in the degree of phase transformation. During cooling from $1400^{\circ} \mathrm{C}$, the $\alpha$-peak remained and the peak intensity continued to increase down to room temperature. This observation conflicts with previous reports in the literature stating that the $\beta$-to- $\alpha$ phase transformation occurs at $\sim 1360^{\circ} \mathrm{C}$ and is reversible. The shift of the $\alpha$-peak to the right was due to thermal expansion and fast cooling $\left(20\right.$ and $60^{\circ} \mathrm{C} / \mathrm{min}$ above and $\left.700^{\circ} \mathrm{C}\right)$. 


\subsection{Effect of $\mathrm{Al}_{2} \mathrm{O}_{3}$ additions}

The influence of $\mathrm{Al}_{2} \mathrm{O}_{3}$ additions on the phase transformation is illustrated in Figure 3, which compares the microstructures of $\mathrm{Ta}_{2} \mathrm{O}_{5}$ samples sintered at $1300^{\circ} \mathrm{C}$ for 99 hours. It is seen that whereas microcracking occurred in the undoped $\mathrm{Ta}_{2} \mathrm{O}_{5}$ (Fig. 3(A)), samples doped with 3 $\mathrm{wt} \% \mathrm{Al}_{2} \mathrm{O}_{3}$ were crack-free. At this dopant level, the solubility limit is exceeded, hence the presence of fine second phase particles $\left(\mathrm{AlTaO}_{4}\right)$ located at the grain boundaries (Fig. 3(B)).

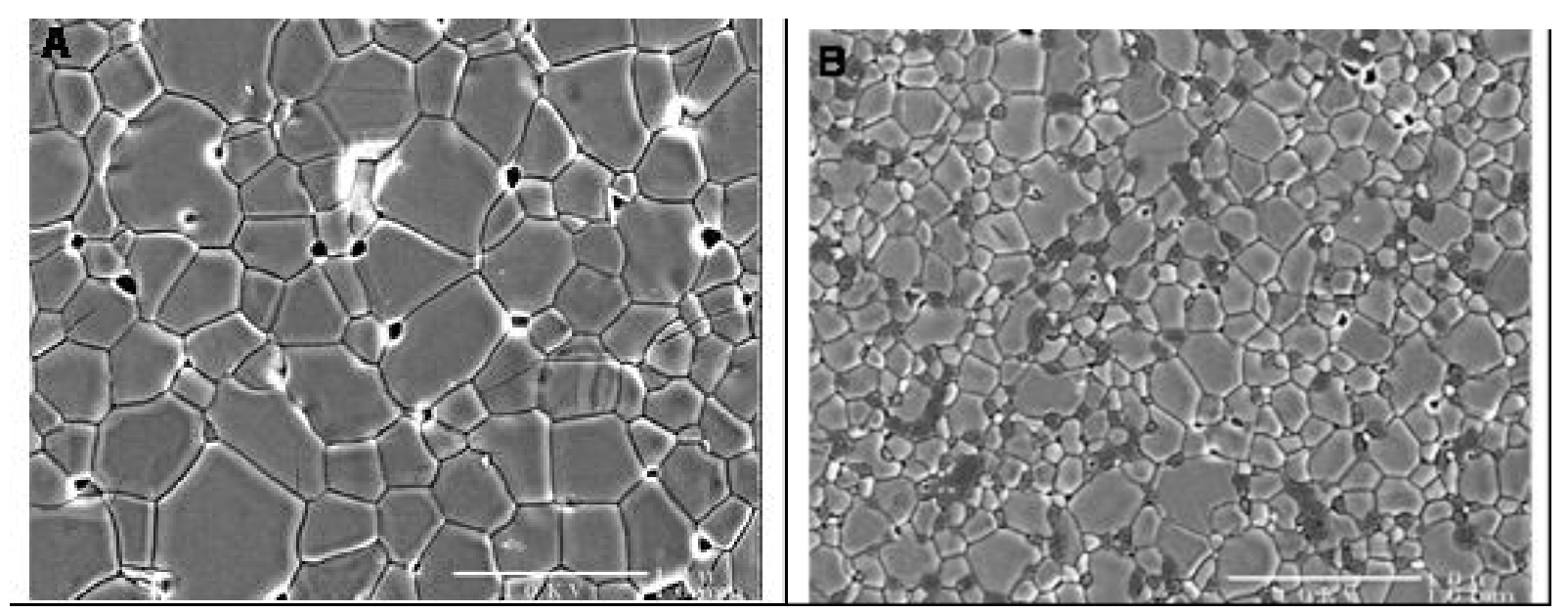

Figure 3. Microstructures of (A) undoped and (B) $3 \mathrm{wt} \% \mathrm{Al}_{2} \mathrm{O}_{3}$-doped $\mathrm{Ta}_{2} \mathrm{O}_{5}$ sintered at $1300^{\circ} \mathrm{C}$ for 99 hours.

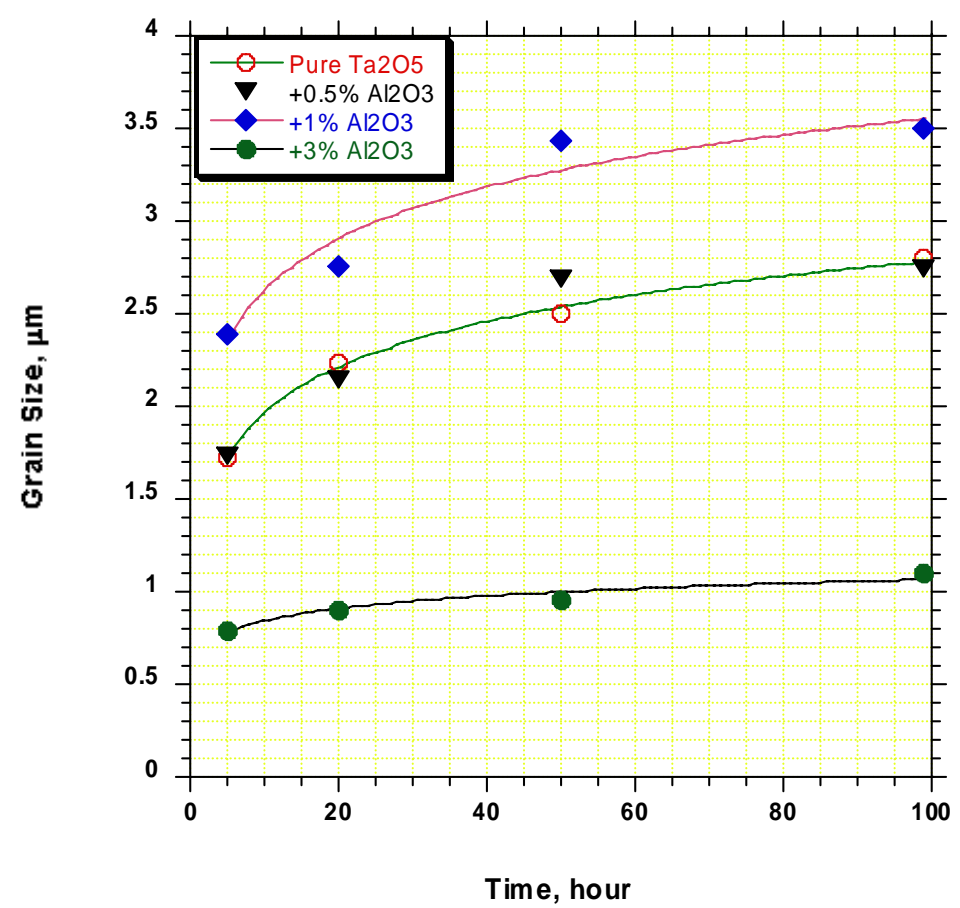

Figure 4. Grain size data of $\mathrm{Ta}_{2} \mathrm{O}_{5}$ doped with various amounts of $\mathrm{Al}_{2} \mathrm{O}_{3}$, sintered at $1300^{\circ} \mathrm{C}$. 
The average grain size of $\mathrm{Ta}_{2} \mathrm{O}_{5}$ samples doped with $0-3 \mathrm{wt} \% \mathrm{Al}_{2} \mathrm{O}_{3}$, and fired at $1300^{\circ} \mathrm{C}$ for different periods of time, are represented in Figure 4 . At the $0.5 \%$ dopant level, the grain size (and microstructure) were very similar to that of the undoped $\mathrm{Ta}_{2} \mathrm{O}_{5}$. However, the sample doped with $1 \% \mathrm{Al}_{2} \mathrm{O}_{3}$ exhibited the largest grain size of the four samples. Figure 4 clearly shows that the highest dopant level studied $(\geq 3 \%)$ resulted in the finest grain size, due to pinning by the $\mathrm{AlTaO}_{4}$ second phase particles.

\subsection{Effect of $\mathrm{La}_{2} \mathrm{O}_{3}$ additions}

The addition of $\mathrm{La}_{2} \mathrm{O}_{3}$ was also found to suppress the $\beta$-to- $\alpha$ phase transformation. The microstructure of a $\mathrm{Ta}_{2} \mathrm{O}_{5}$ sample doped with $1.5 \% \mathrm{La}_{2} \mathrm{O}_{3}$ (fired at $1340{ }^{\circ} \mathrm{C}$ for 10 hours) is shown in Figure 5. It was observed that as the $\mathrm{La}_{2} \mathrm{O}_{3}$ content increased, the density of the sintered samples decreased. Note that for an undoped $\mathrm{Ta}_{2} \mathrm{O}_{5}$ sample, the same heat-treatment resulted in the sample being broken into small fragments. A distinguishing feature of the microstructures of the $\mathrm{La}_{2} \mathrm{O}_{3}$-doped samples is the presence of elongated grains of the second phase $\mathrm{LaTa}_{7} \mathrm{O}_{19}$.

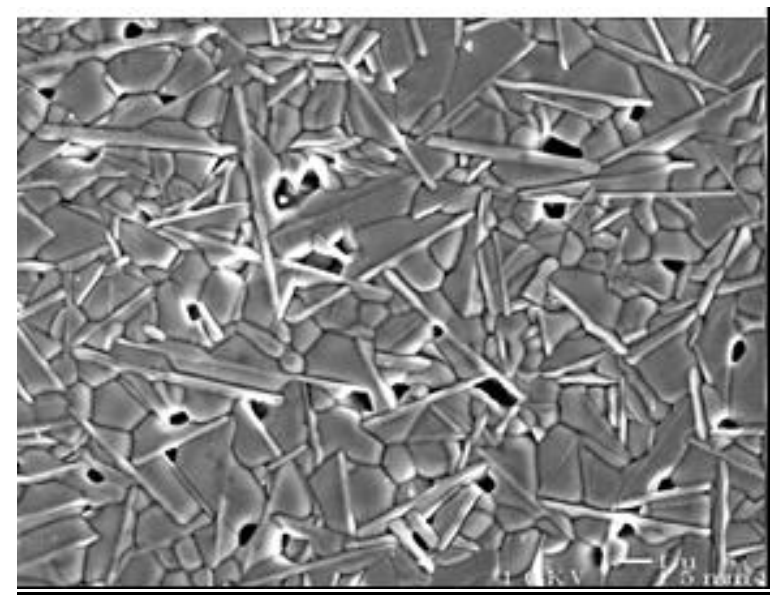

Figure 5. Microstructure of $1.5 \mathrm{wt} \% \mathrm{La}_{2} \mathrm{O}_{3}$-doped $\mathrm{Ta}_{2} \mathrm{O}_{5}$ sintered at $1340^{\circ} \mathrm{C}$ for 10 hours.

\section{$2.4 \quad$ Effect of $\mathrm{Nb}_{2} \mathrm{O}_{5}$ additions}

The microstructures of the fired samples containing varying amounts $(1-5 \mathrm{wt} \%)$ of $\mathrm{Nb}_{2} \mathrm{O}_{5}$ are given in Figure 6. Microcracking occurred in all samples, indicating that the $\beta$-to- $\alpha$ phase transformation had taken place during firing. Furthermore, in contrast to the results for $\mathrm{Al}_{2} \mathrm{O}_{3}$ and $\mathrm{La}_{2} \mathrm{O}_{3}$ containing compositions, $\mathrm{Nb}_{2} \mathrm{O}_{5}$ additions (for corresponding dopant levels), did not result in the formation of second phase particles. 


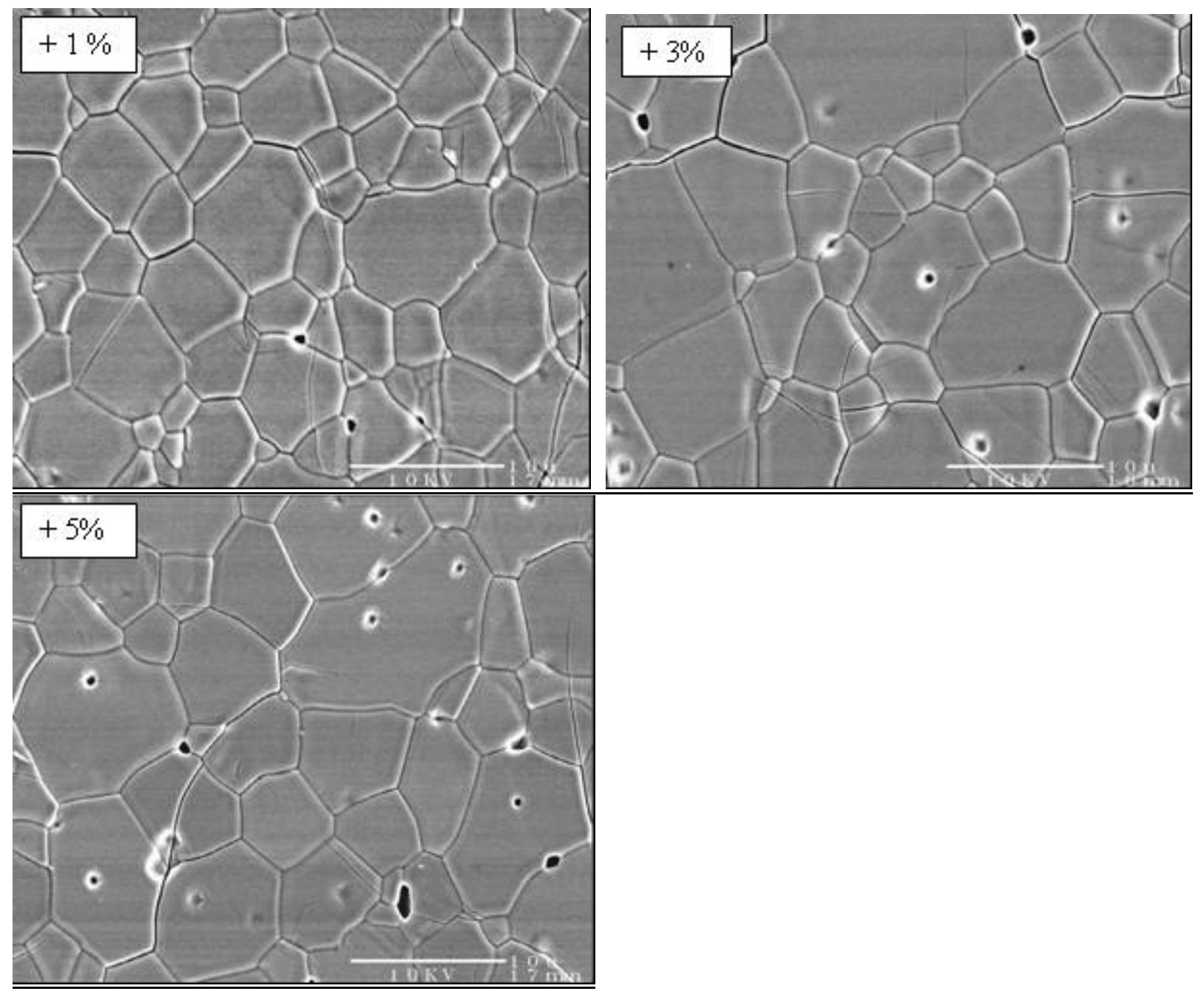

Figure 6. Microstructures of 1,3 and $5 \mathrm{wt} \% \mathrm{Nb}_{2} \mathrm{O}_{5}$ doped $\mathrm{Ta}_{2} \mathrm{O}_{5}$ fired at $1380^{\circ} \mathrm{C}$ for $5 \mathrm{hrs}$. Note that microcracking is common in all samples indicating that the $\beta$-to- $\alpha$ phase has occurred to some extent during firing.

\subsection{Co-doping of $\mathrm{Ta}_{2} \mathrm{O}_{5}$ with $\mathrm{Al}_{2} \mathrm{O}_{3} / \mathrm{La}_{2} \mathrm{O}_{3}$}

Representative microstructures of samples of $\mathrm{Ta}_{2} \mathrm{O}_{5}$ co-doped with $2 \mathrm{wt} \% \gamma-\mathrm{Al}_{2} \mathrm{O}_{3}$ and 1 $\mathrm{wt} \% \mathrm{La}_{2} \mathrm{O}_{3}$, are depicted in Figure 7. The elongated grains are a $\mathrm{La}_{2} \mathrm{O}_{3}$-rich phase $\left(\mathrm{LaTa}_{7} \mathrm{O}_{19}\right)$ and the small dark particles are an $\mathrm{Al}_{2} \mathrm{O}_{3}$-rich phase $\left(\mathrm{AlTaO}_{4}\right)$. The second phase particles are uniformly distributed in the $\mathrm{Ta}_{2} \mathrm{O}_{5}$ matrix. The combined addition of $\mathrm{Al}_{2} \mathrm{O}_{3}$ and $\mathrm{La}_{2} \mathrm{O}_{3}$ worked together to effectively stabilize the low-temperature crystal structure $(\beta)$ and refine the $\mathrm{Ta}_{2} \mathrm{O}_{5}$ microstructure. Only limited microcracking was observed in the sample fired at $1450^{\circ} \mathrm{C}$ for 5 hours (Figure 7(C)). 

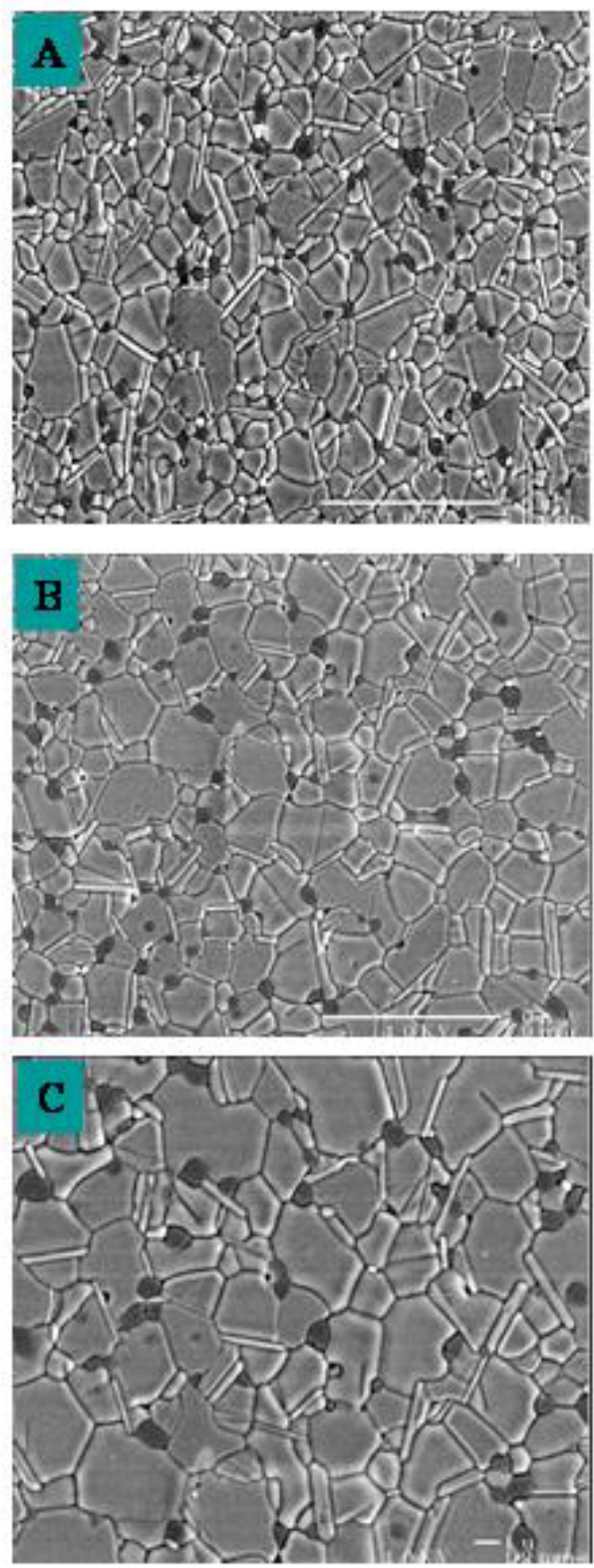

Figure 7. Microstructures of $\mathrm{Ta}_{2} \mathrm{O}_{5}$ doped with $2 \mathrm{wt} \% \gamma-\mathrm{Al}_{2} \mathrm{O}_{3}$ and $1 \mathrm{wt} \% \mathrm{La}_{2} \mathrm{O}_{3}$, fired at (A) $1350^{\circ} \mathrm{C}$, (B) $1400^{\circ} \mathrm{C}$ and (C) $1450^{\circ} \mathrm{C}$ for 5 hours.

\subsection{Thermal Expansion of $\mathrm{Ta}_{2} \mathrm{O}_{5}$ co-doped with $\mathrm{Al}_{2} \mathrm{O}_{3}$ and $\mathrm{Nb}_{2} \mathrm{O}_{5}$}

The thermal expansion behavior of $\mathrm{Ta}_{2} \mathrm{O}_{5}$ co-doped with $\mathrm{Al}_{2} \mathrm{O}_{3}$ and $\mathrm{Nb}_{2} \mathrm{O}_{5}$ was measured and the data are presented in Figure 8. As expected, the co-doping of $\mathrm{Nb}_{2} \mathrm{O}_{5}$ and $\mathrm{Al}_{2} \mathrm{O}_{3}$ was beneficial with regard to matching the thermal expansion coefficients of AS800 $\mathrm{Si}_{3} \mathrm{~N}_{4}$ and the coating material. It can be seen that the expansion curves of the samples doped with 5 and 7 $\mathrm{wt} \% \mathrm{Nb}_{2} \mathrm{O}_{5}$ are almost identical, and closely match that of the AS800. The measured thermal expansion coefficients for the $\mathrm{Ta}_{2} \mathrm{O}_{5}$ co-doped with $\mathrm{Al}_{2} \mathrm{O}_{3}$ and $\mathrm{Nb}_{2} \mathrm{O}_{5}$, and some related materials are listed in Table 4. 


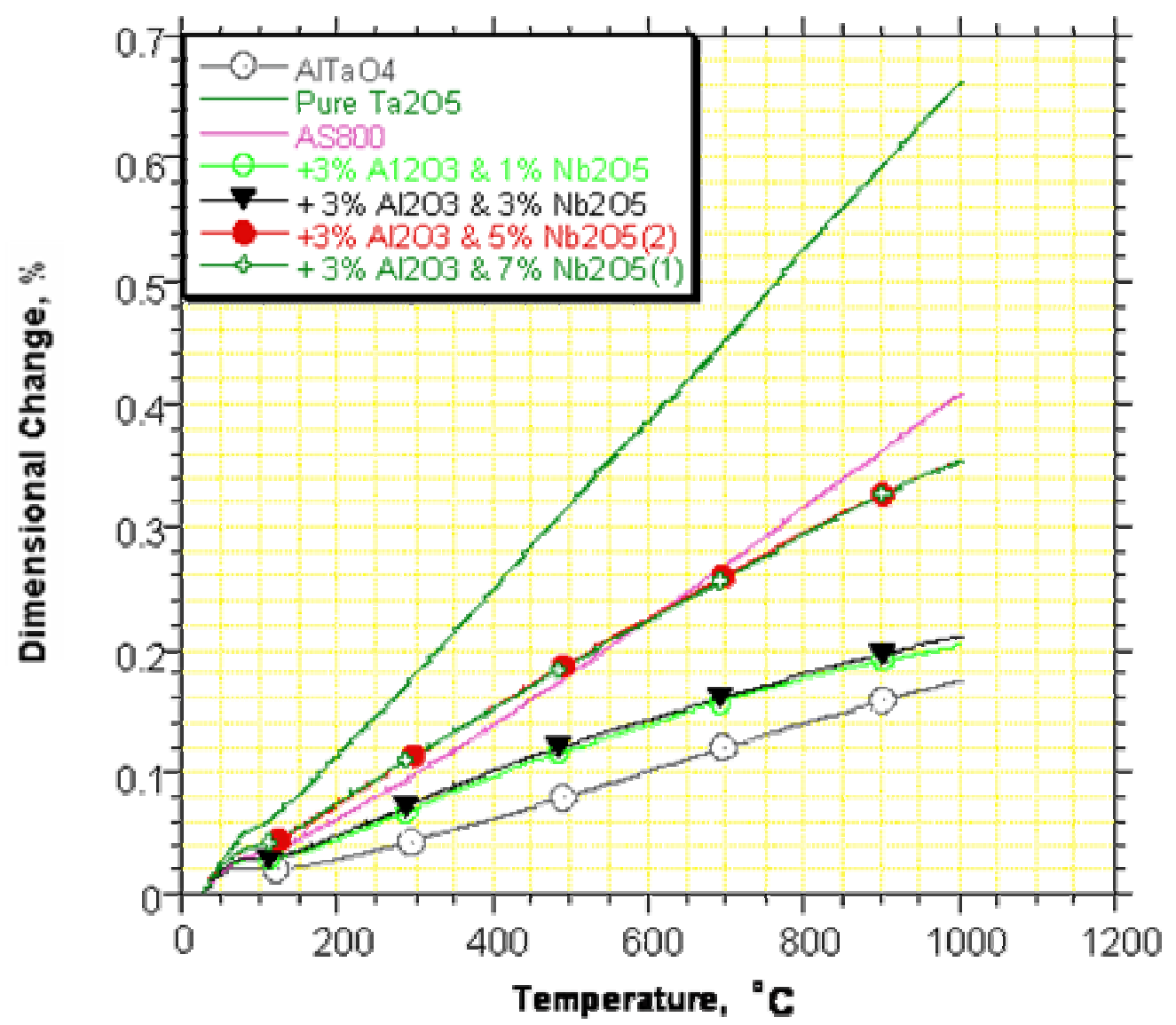

Figure 8. Thermal expansion behavior of $\mathrm{Ta}_{2} \mathrm{O}_{5}$ co-doped with $3 \mathrm{wt} \% \mathrm{Al}_{2} \mathrm{O}_{3}$ and various amounts of $\mathrm{Nb}_{2} \mathrm{O}_{5}$. Data for $\mathrm{AlTaO}_{4}$ and $\mathrm{AS} 800 \mathrm{Si}_{3} \mathrm{~N}_{4}$ are also plotted for comparison.

Table 4. Thermal expansion coefficients of $\mathrm{Ta}_{2} \mathrm{O}_{5}, \mathrm{AlTaO}_{4}$ and $\mathrm{AS} 800 \mathrm{Si}_{3} \mathrm{~N}_{4}$ ceramics in a temperature range up to $1000^{\circ} \mathrm{C}$.

\begin{tabular}{|l|c|}
\hline Material & Thermal Expansion Coefficient \\
\hline $\mathrm{AlTaO}$ & $1.84 \times 10^{-6}$ \\
\hline $\mathrm{Ta}_{2} \mathrm{O}_{5}$ doped with $3 \% \mathrm{Al}_{2} \mathrm{O}_{3}$ & $2.42 \times 10^{-6}$ \\
\hline $\mathrm{Ta}_{2} \mathrm{O}_{5}$ doped with $3 \% \mathrm{Al}_{2} \mathrm{O}_{3}$ and $5 \%$ or $7 \% \mathrm{Nb}_{2} \mathrm{O}_{5}$ & $3.54 \times 10^{-6}$ \\
\hline $\mathrm{AS} 800 \mathrm{Si}_{3} \mathrm{~N}_{4}$ & $4.33 \times 10^{-6}$ \\
\hline $\mathrm{Pure} \mathrm{Ta}_{2} \mathrm{O}_{5}$ & $6.72 \times 10^{-6}$ \\
\hline $\mathrm{Ta}_{2} \mathrm{O}_{5}$ doped with $3 \% \mathrm{Al}_{2} \mathrm{O}_{3}$ and $1 \%$ or $3 \% \mathrm{Nb}_{2} \mathrm{O}_{5}$ & $2.14 \times 10^{-6}$ \\
\hline
\end{tabular}




\section{Task 3: Life Limiting Phenomena}

To characterize the suitability of SPPS coatings for engine applications which contain water vapor in the combustion atmosphere, $\mathrm{Ta}_{2} \mathrm{O}_{5}$-coated AS800 was exposed to a series of static and cyclic heat treatments, cyclic steam exposures at Honeywell, and Keiser Rig exposures (reported on by Oak Ridge National Laboratory). Materials which underwent these exposures were evaluated for microstructural changes and for residual stress changes. In the case of cyclic steam exposures, changes in mass were also evaluated. The results of those tests are presented here.

\section{1 Thermal cycling tests}

Using a high temperature cyclic oxidation furnace (procured outside the scope of this program using Honeywell capital resources), Honeywell completed cyclical heat-treatment tests on a number of Northwestern-sprayed samples of uncoated AS800 and coatings of pure $\mathrm{Ta}_{2} \mathrm{O}_{5}$, $\mathrm{Ta}_{2} \mathrm{O}_{5}+2 \mathrm{wt} \% \mathrm{Al}_{2} \mathrm{O}_{3}, \mathrm{Ta}_{2} \mathrm{O}_{5}+3 \mathrm{wt} \% \mathrm{Al}_{2} \mathrm{O}_{3}, \mathrm{Ta}_{2} \mathrm{O}_{5}+5 \mathrm{wt} \% \mathrm{Al}_{2} \mathrm{O}_{3}$, and $\mathrm{Ta}_{2} \mathrm{O}_{5}+3 \mathrm{wt} \% \mathrm{Al}_{2} \mathrm{O}_{3}+$ $3 \mathrm{wt} \% \mathrm{La}_{2} \mathrm{O}_{3}$. Three separate rounds of tests were conducted as described below. In all cases the thermal cycle was as follows: 25 minutes in the furnace, 5 minutes out of the furnace in forced room temperature air stream. A picture of the furnace used to conduct the thermal cycling is shown in Appendix C.

\section{$\underline{\text { Round } 1}$}

The first set of twenty-five samples was thermal cycled for up to 3358 cycles at either $1200{ }^{\circ} \mathrm{C}$ and/or $1315^{\circ} \mathrm{C}$. A summary of the samples and conditions is shown in Appendix D. In general, all coatings performed well under thermal cycling conditions, with the exception of some undoped $\mathrm{Ta}_{2} \mathrm{O}_{5}$ coatings, and all of the $\mathrm{Ta}_{2} \mathrm{O}_{5}+5 \mathrm{wt} \% \mathrm{Al}_{2} \mathrm{O}_{3}$ coatings. Only the $\mathrm{Ta}_{2} \mathrm{O}_{5}+3$ $\mathrm{wt} \% \mathrm{Al}_{2} \mathrm{O}_{3}+3 \mathrm{wt} \% \mathrm{La}_{2} \mathrm{O}_{3}$ was seen to survive more than 3000 cycles to $1315^{\circ} \mathrm{C}$. Following testing all samples were sent to Northwestern for further examination.

Photographs showing samples upon removal from the hot furnace are attached. Figure 9 shows a large group of samples after 2 thermal cycles to $1200^{\circ} \mathrm{C}$. In this photograph, subsurface defects can be seen. It is uncertain as to the cause of these defects, but during continued cycling the coating at that region was seen to crack and spalled from the substrate. Figure 10 and Figure 11 show a small group of samples after more than 650 and 1315 cycles at $1315^{\circ} \mathrm{C}$. In these photos, damage can be seen to progress on the edge of the Pure $\mathrm{Ta}_{2} \mathrm{O}_{5}$ coated-sample. No subsurface damage can be seen. 


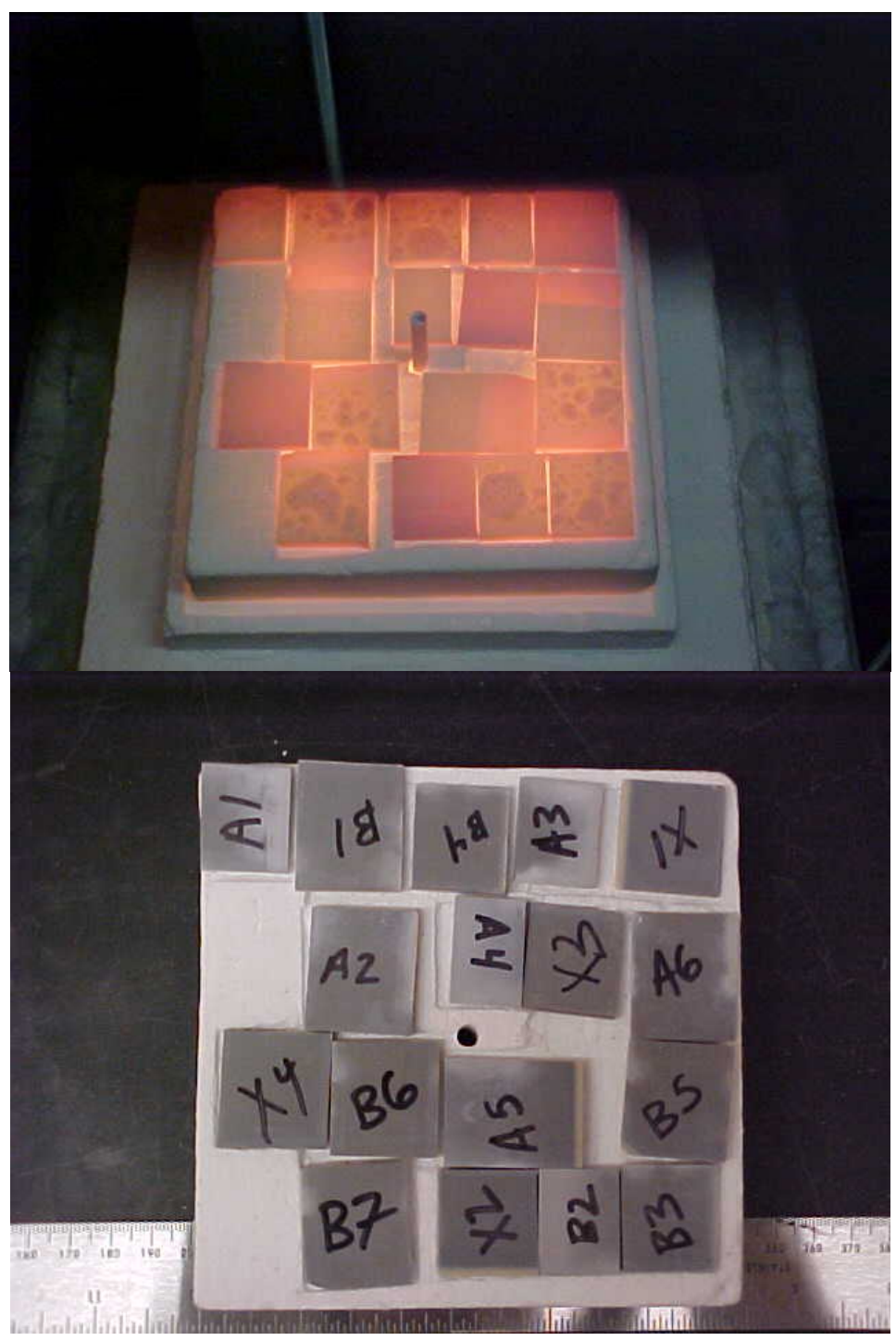

Figure 9. Upper photograph showing thermal cycling samples after 2 cycles at $1200^{\circ} \mathrm{C}$, upon removal from furnace (samples hot). The non-uniform, mottled appearance indicates sub-surface delamination. Lower photograph gives sample number (see Appendix D) and scale. 


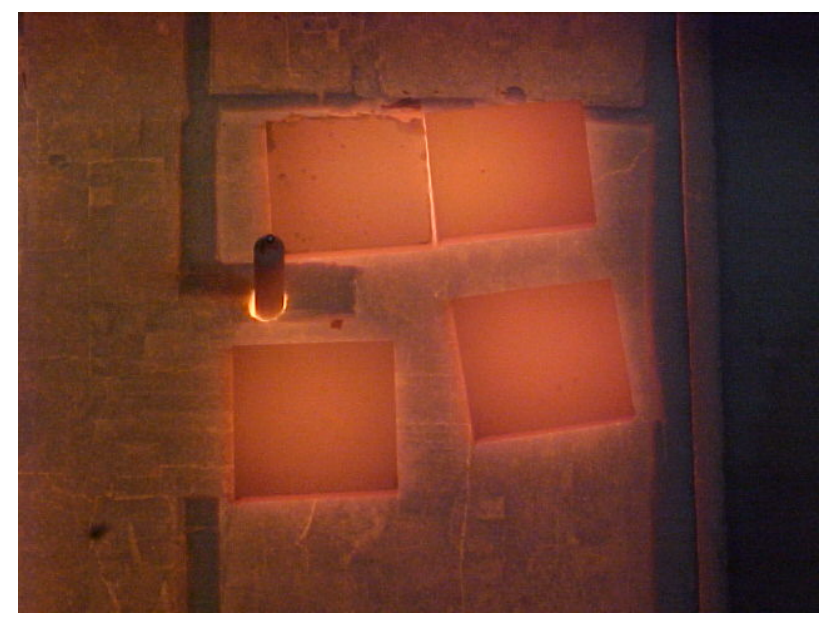

Figure 10. Thermal cycling samples after 770 cycles. Samples are approximately $25 \times 25 \mathrm{~mm}$. Samples shown are (clockwise from upper left): A7, C3, E1, D3 (see Appendix D). Sample A7 (pure $\mathrm{Ta}_{2} \mathrm{O}_{5}$ ) shows signs of delamination at the edges.

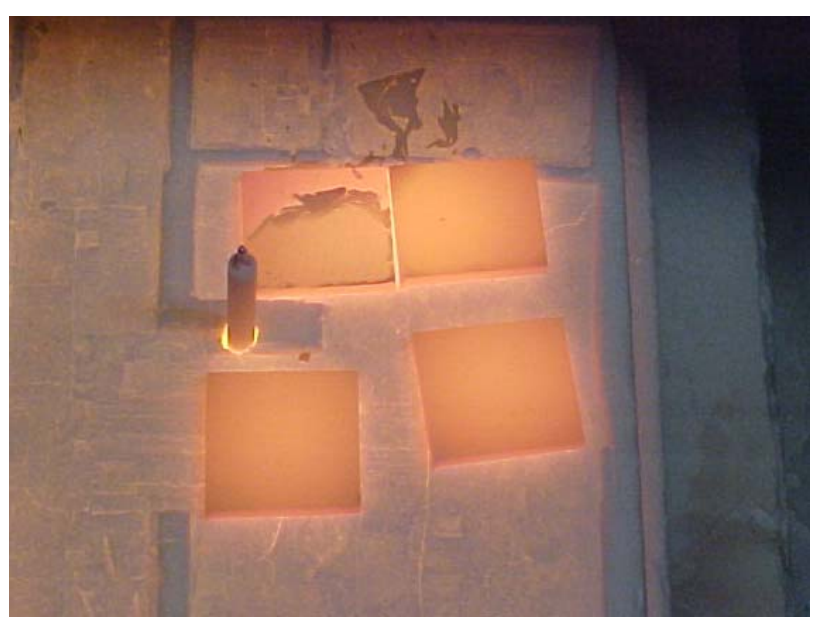

Figure 11. Thermal cycling samples after 1416 cycles. Samples are approximately 25 x $25 \mathrm{~mm}$. Samples shown are (clockwise from upper left): A7, C3, E1, D3 (see Appendix D). Sample A7 (pure $\mathrm{Ta}_{2} \mathrm{O}_{5}$ ) shows signs of progressive delamination at the edges. 


\section{Round 2:}

The second set of sixteen samples was thermal cycled for either 140, 490, or 1080 cycles between room temperature and $1200^{\circ} \mathrm{C}$. All samples were plasma sprayed with either $\mathrm{Ta}_{2} \mathrm{O}_{5}+$ $1.5 \mathrm{wt} \% \mathrm{Al}_{2} \mathrm{O}_{3}$ or $\mathrm{Ta}_{2} \mathrm{O}_{5}+1.5 \mathrm{wt} \% \mathrm{Al}_{2} \mathrm{O}_{3}+1.5 \mathrm{wt} \% \mathrm{La}_{2} \mathrm{O}_{3}$. A summary of the samples and conditions is shown in Appendix E. All samples survived testing without any noted delamination, and were sent to Northwestern so that they could be studied using the Argonne National Lab (ANL) Advanced Photon Source (APS) to determine the effect of thermal cycles on the residual stress state in the samples.

\section{Round 3:}

The third set of six samples was thermal cycled for 1000 cycles between room temperature and $1200{ }^{\circ} \mathrm{C}$, followed by 1000 cycles between room temperature and $1315^{\circ} \mathrm{C}$. All samples were plasma sprayed with either $\mathrm{Ta}_{2} \mathrm{O}_{5}+1.5 \mathrm{wt} \% \mathrm{Al}_{2} \mathrm{O}_{3}$ or $\mathrm{Ta}_{2} \mathrm{O}_{5}+1.5 \mathrm{wt} \% \mathrm{Al}_{2} \mathrm{O}_{3}+$ $1.5 \mathrm{wt} \% \mathrm{La}_{2} \mathrm{O}_{3}$. A summary of the samples and conditions is shown in Table 5 below. All samples survived testing without any noted delamination. Following thermal cycling, samples AL1 and ALLA1 were subjected to steam furnace testing as will be described in a later section. All other AL and ALLA samples were sent to Northwestern for further study and archiving.

Table 5: Summary log of thermal cycling samples from Round 3

\begin{tabular}{|c|c|c|c|}
\hline Coating composition & $\begin{array}{l}\text { \#cycles@ } \\
1200^{\circ} \mathrm{C}\end{array}$ & $\begin{array}{l}\text { \#cycles@ } \\
1315^{\circ} \mathrm{C}\end{array}$ & Results, observations \\
\hline \multicolumn{4}{|l|}{ Group AL: $\mathrm{Ta}_{2} \mathrm{O}_{5}+1.5 \mathrm{wt} \% \mathrm{Al}_{2} \mathrm{O}_{3}$} \\
\hline $\begin{array}{ll}\text { sample AL1 } & \\
\text { sam }\end{array}$ & 1000 & 1000 & No delamination seen \\
\hline sample AL2 & 1000 & 1000 & No delamination seen \\
\hline sample AL3 & 1000 & 1000 & No delamination seen \\
\hline sample AL4 & 1000 & 1000 & No delamination seen \\
\hline \multicolumn{4}{|l|}{$\begin{array}{l}\text { Group ALLA: } \mathrm{Ta}_{2} \mathrm{O}_{5}+1.5 \mathrm{wt} \% \\
\mathrm{Al}_{2} \mathrm{O}_{3}+1.5 w t \% \mathrm{La}_{2} \mathrm{O}_{3}\end{array}$} \\
\hline sample ALLA1 & 1000 & 1000 & No delamination seen \\
\hline sample ALLA2 & 1000 & 1000 & No delamination seen \\
\hline
\end{tabular}

\subsection{Residual stress measurements}

X-ray diffraction measurements were conducted on both the statically heat-treated and thermally cycled samples using high-energy synchrotron radiation at the 1-ID (XOR-CAT) beam line of the Advanced Photon Source at Argonne National Laboratory. Diffraction data were used to determine residual stresses in the AS800 substrates and both phase evolution and residual stresses in the tantalum oxide coatings as a function of heat treatment. Residual stresses were also determined in as-received and thermally-cycled uncoated AS800 substrates. As-sprayed and heat-treated specimens were cross-sectioned to create $0.5-1 \mathrm{~mm}$ thick slices. The experiments 
were conducted in transmission as illustrated in Figure 12, which afforded a through-thethickness residual stress profile in $20 \mu \mathrm{m}$ increments, in contrast to the reflection geometry which only provides residual stress assessment in the exterior tens of microns.

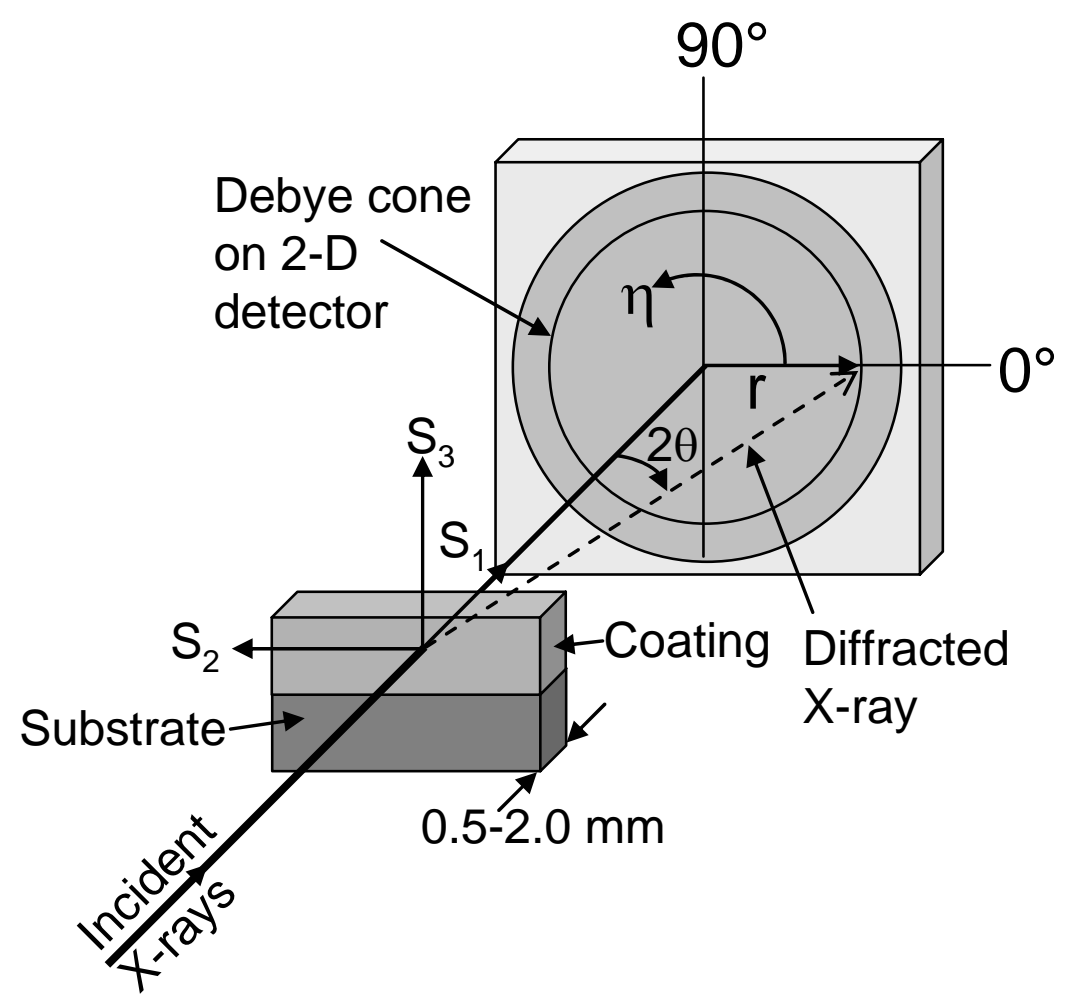

Figure 12. Schematic of the X-ray diffraction set up at the Advanced Photon source of Argonne National Laboratory for residual stress measurement.

AS800 was found to have compressive residual stresses near the surface due to a postprocessing heat treatment. These stresses remained compressive regardless of the stress state of the coating although the stress profile with depth was found to change with additional heat treatment.

Though numerical analysis of the bulk properties of $\mathrm{Ta}_{2} \mathrm{O}_{5}$ and AS800 indicated that the coating should be in compression, as-sprayed coatings were measured to be in tension (Figure 13), most likely due to the non-equilibrium nature of the plasma-spray process. Tensile quenching stresses that developed due to shrinkage of individual splats during solidification had a significant effect on the residual stress state of the coating. In addition, as-sprayed coatings contained the high-temperature $\alpha-\mathrm{Ta}_{2} \mathrm{O}_{5}$ phase which could also affect coating stresses. Heat treatments (static or cyclic) produced an equilibrium $\beta-\mathrm{Ta}_{2} \mathrm{O}_{5}$ coating with compressive stresses more consistent with numerically-predicted equilibrium thermal mismatch stresses, also shown in Figure 13. Vertical macro-cracking in as-sprayed coatings as well as buckling and microcracking in heat-treated coatings both led to a stress relaxation of residual stresses. Macrocracks formed due to high tensile stresses after plasma spraying, but healed during initial heat 
treatments. Buckling occurred in heat-treated coatings due to high compressive stresses, and was evident in cross-sections examined by scanning electron microscopy (Figure 14).

Microcracks resulted from grain growth in the $\mathrm{Ta}_{2} \mathrm{O}_{5}$ due to its anisotropic coefficient of thermal expansion. Though the cracks in the coating relieved stresses, they would be detrimental for an environmental barrier since they would provide a pathway for the gas turbine environment to reach the silicon nitride ceramic. Buckling can also lead to large scale spallation of the coating, also exposing the ceramic underneath. Hence, it was determined that pure $\mathrm{Ta}_{2} \mathrm{O}_{5}$ is not a viable coating in an EBC system for use with silicon nitride.

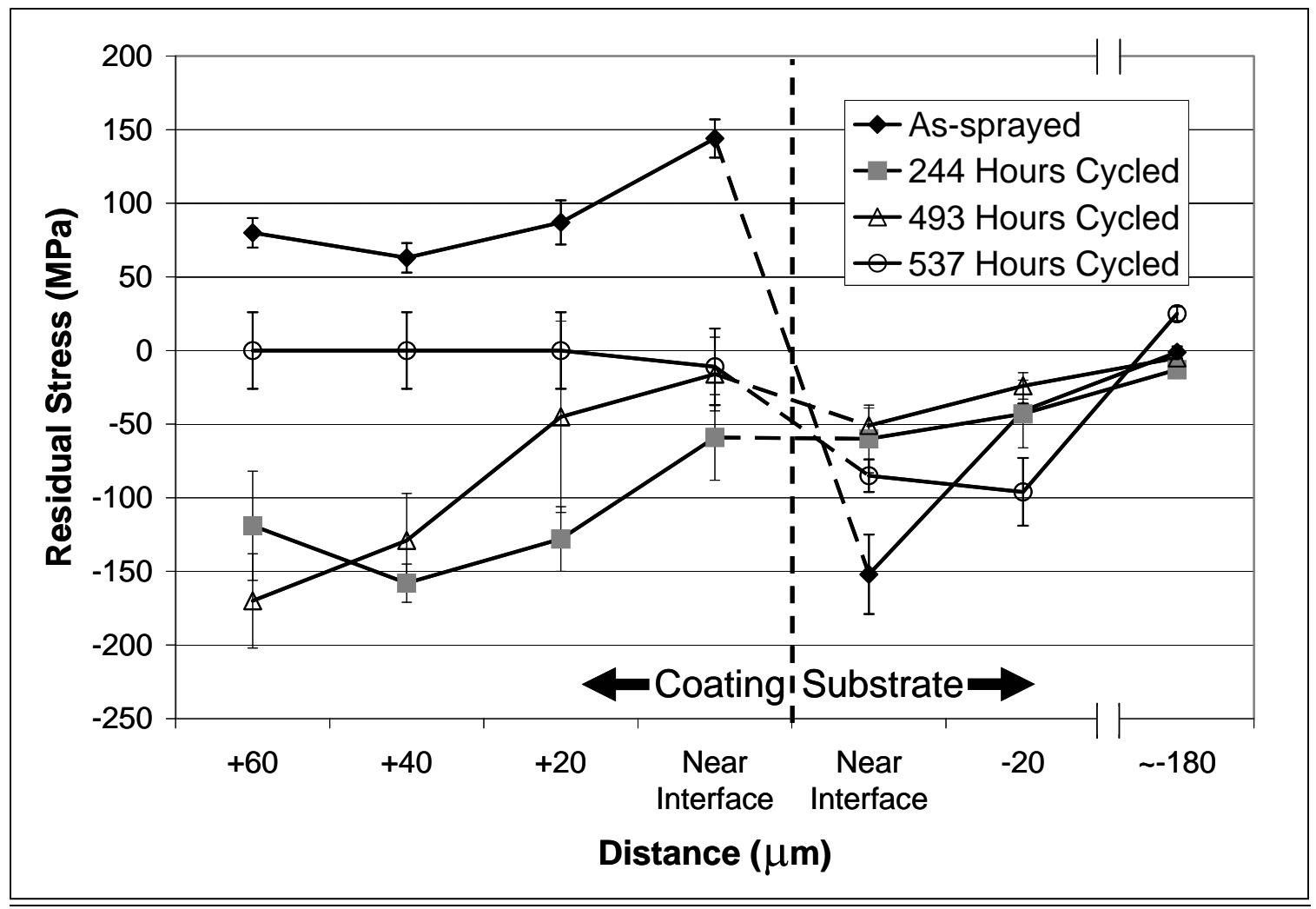

Figure 13. Residual stress results for as-sprayed and cyclically heat-treated (30 min. cycles to $1200^{\circ} \mathrm{C}$ in air) coatings on AS800. 


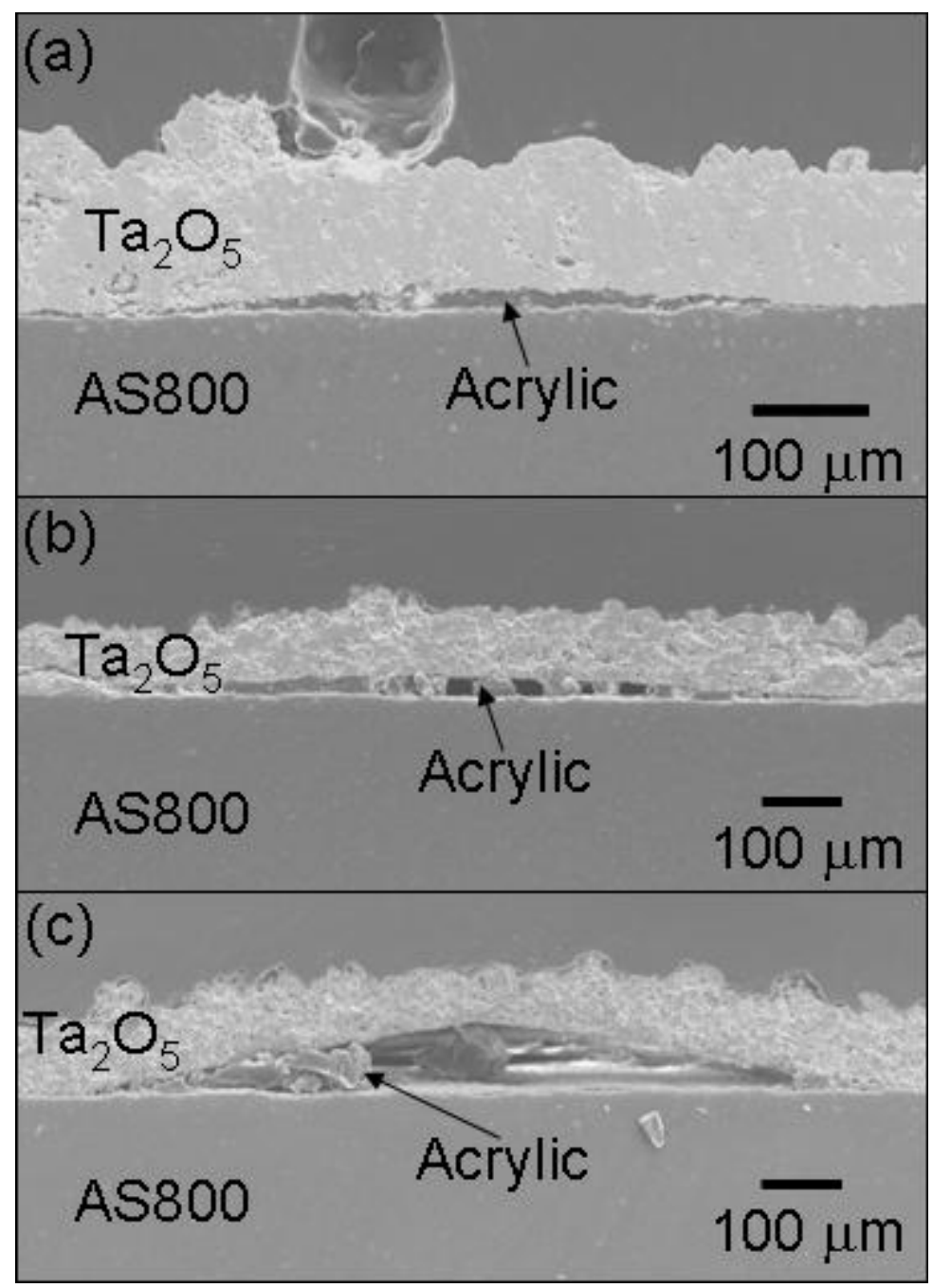

Figure 14. Micrographs showing buckling in coatings cyclically heat treated for (a) 72 hours, (b) 493 hours and (c) 537 hours. Some of the mounting acrylic, found between the coating and substrate, pulled out during polishing in (b) and (c).

Four compositions of alloyed powders of $\mathrm{Ta}_{2} \mathrm{O}_{5}$ containing $\mathrm{Al}_{2} \mathrm{O}_{3}$ or $\mathrm{Al}_{2} \mathrm{O}_{3} / \mathrm{La}_{2} \mathrm{O}_{3}$ were small particle plasma sprayed on AS800 and heat treated to $1200^{\circ} \mathrm{C}$ in air. Residual stresses in all these coatings were determined to be tensile indicating that the alloyed coatings had coefficients of thermal expansion that are higher than AS800. The alloying additions successfully reduced grain growth in the coatings, as displayed in Figure 15, and microcrack formation was eliminated in coatings containing $\mathrm{La}_{2} \mathrm{O}_{3}$. The $\mathrm{Ta}_{2} \mathrm{O}_{5}+1.5$ wt. $\% \mathrm{Al}_{2} \mathrm{O}_{3}+1.5$ wt. $\%$ $\mathrm{La}_{2} \mathrm{O}_{3}$ alloy showed the most promise for use as an environmental barrier coating due to the microstructural stability, as evidenced by nearly invariant residual stress with heat treatment and lack of microcracking, shown in Figure 16. Exposure of $\mathrm{Ta}_{2} \mathrm{O}_{5}+1.5$ wt. $\% \mathrm{Al}_{2} \mathrm{O}_{3}$ and $\mathrm{Ta}_{2} \mathrm{O}_{5}+$ 1.5 wt. $\% \mathrm{Al}_{2} \mathrm{O}_{3}+1.5$ wt. $\% \mathrm{La}_{2} \mathrm{O}_{3}$ coated AS800 samples to thermal cycling in air for 500 hours at $1200^{\circ} \mathrm{C}$ and 500 hours at $1315^{\circ} \mathrm{C}$ did not lead to spallation of the coatings. 


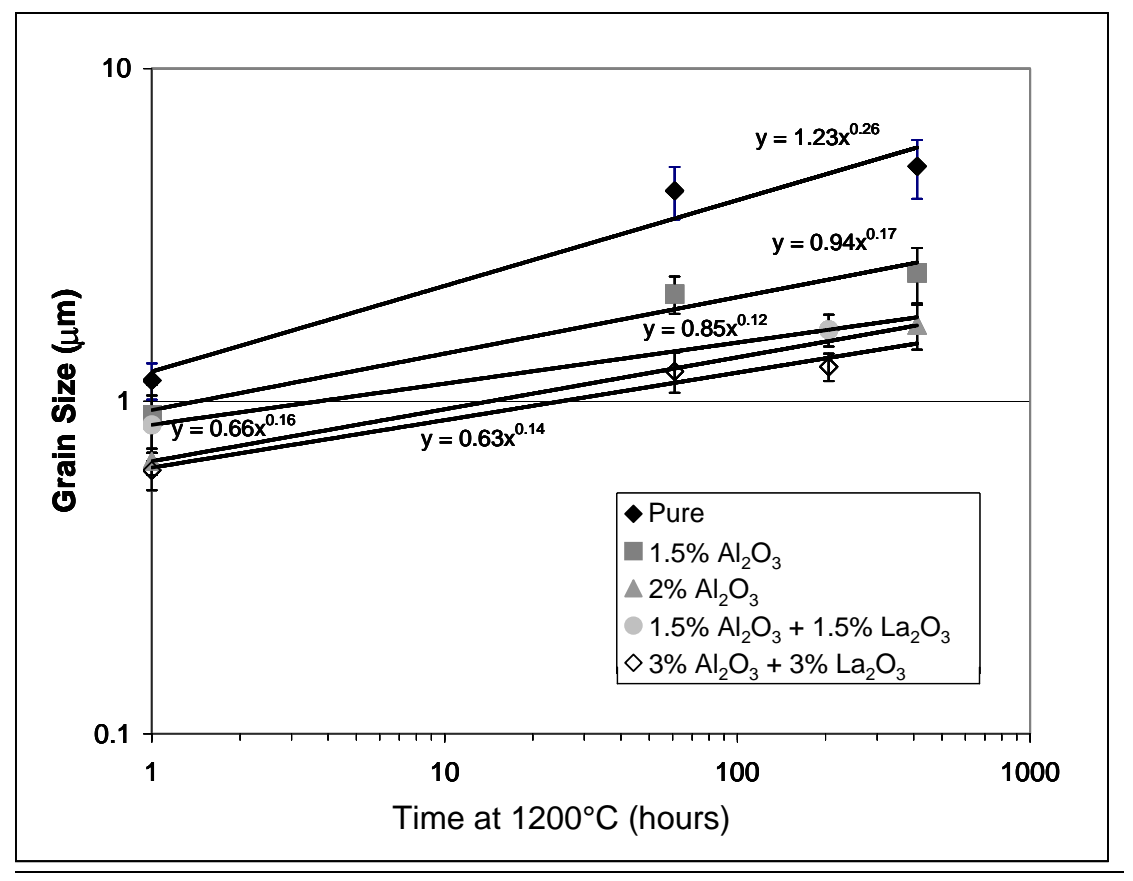

Figure 15. Grain size as a function of time at temperature for cyclically heat-treated pure and alloyed $\mathrm{Ta}_{2} \mathrm{O}_{5}$ coatings determined from stereology measurements. Error bars represent one standard deviation.

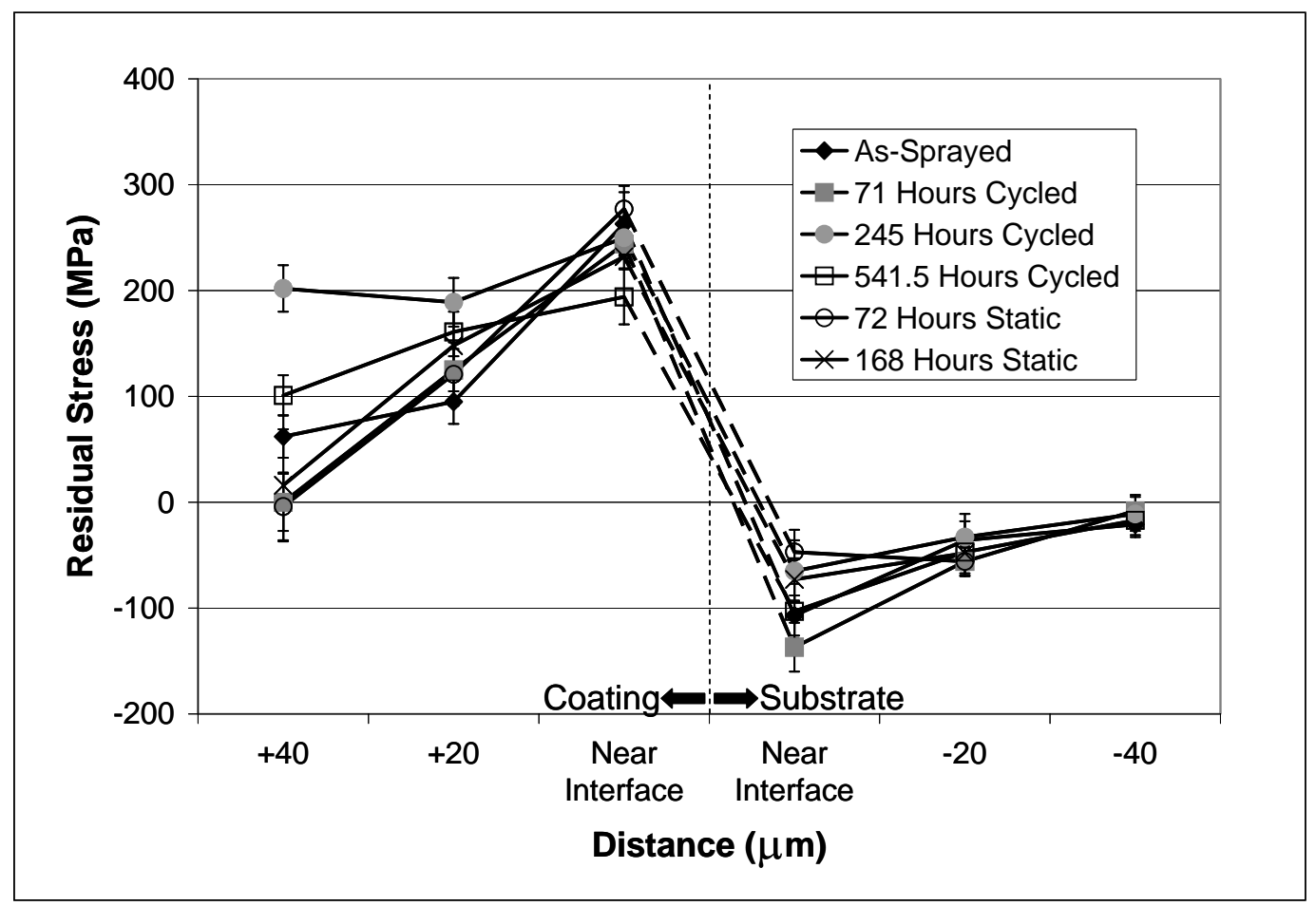

Figure 16. Residual stresses determined for as-sprayed and heat-treated coatings of $\mathrm{Ta}_{2} \mathrm{O}_{5}$ with $1.5 \mathrm{wt} \% \mathrm{Al}_{2} \mathrm{O}_{3}+1.5 \mathrm{wt} \% \mathrm{La}_{2} \mathrm{O}_{3}$ on AS 800 substrates. 


\subsection{Steam Furnace Testing}

After samples (identified in Appendix D) had each been previously thermal cycled for 1000 cycles to $1200^{\circ} \mathrm{C}$ then 1000 cycles to $1315^{\circ} \mathrm{C}$ without failure, samples AL1 and ALLA1 were supported on silicon nitride bars and put into a $76 \mathrm{~mm}$ diameter $\mathrm{SiC}$ tube furnace heated to $1315^{\circ} \mathrm{C}$. Water was peristaltically pumped into one end at a flowrate of approximately 2.9 $\mathrm{ml} / \mathrm{min}$. Steam exited the furnace at either end. The estimated steam velocity was estimated to be approximately 2 meters per minute. Each end of the tube had a $6 \mathrm{~mm}$ diameter hole open to the laboratory atmosphere. Therefore the water vapor pressure was assumed to be approximately 1 atmosphere.

The specimens were removed periodically to assess mass change. The mass change results are shown in Figure 17. The coated samples were removed at 209 hours at which time complete delamination of the coating from the substrate was noted.

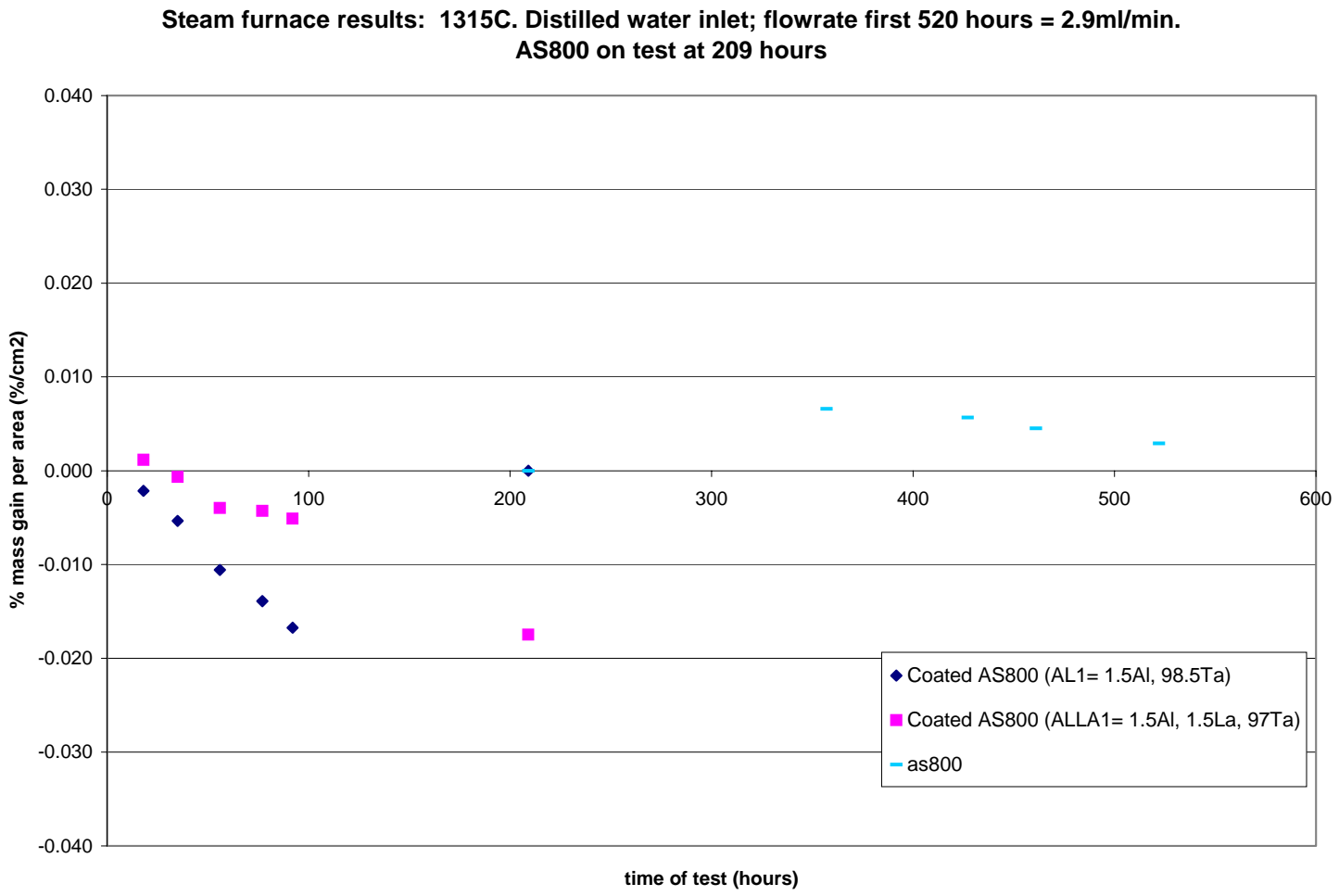

Figure 17. Weight gain as a function of time at $1315^{\circ} \mathrm{C}$ in Honeywell's steam furnace.

After the coated specimens were removed due to delamination, an AS800 specimen of approximately the same size with one surface "As-fired" was put into the furnace and was run for approximately another 300 hours. The mass change for the AS800 specimen is also shown in Figure 17. However, unlike the coated AS800 specimens, the uncoated AS800 had not been previously heat treated to $1250^{\circ} \mathrm{C}$ for $0.5 \mathrm{~h}$ (to stabilize the oxynitride grain boundary phases), nor had it been thermal cycled to $1200^{\circ} \mathrm{C} / 1315^{\circ} \mathrm{C}$ for $1000 / 1000$ cycles, respectively. (For the 
coated specimens, the total time at temperature prior to water vapor testing was approximately $0.5 \mathrm{~h}$ at $1250^{\circ} \mathrm{C}$ (before being coated), 416 hours at $1200^{\circ} \mathrm{C}$ (coated), and 416 hours at $1315^{\circ} \mathrm{C}$ (coated)).

After completion of the test, the steam-exposed coated and uncoated AS800 specimens were sent to Northwestern for further study and archiving.

\subsection{Keiser Rig Testing}

Eight pure $\mathrm{Ta}_{2} \mathrm{O}_{5}$-coated AS800 substrates were provided to Oak Ridge National Laboratory for Keiser Rig testing at $1315^{\circ} \mathrm{C}$ and $3 \% \mathrm{H}_{2} \mathrm{O}$ for 500 hours. These tests showed that undoped $\mathrm{Ta}_{2} \mathrm{O}_{5}$ is not an effective barrier at preventing sub-coating chemical changes to the AS800 substrate. $\mathrm{Ta}_{2} \mathrm{O}_{5}$-coated samples containing $\mathrm{Al}_{2} \mathrm{O}_{3}$ and $\mathrm{La}_{2} \mathrm{O}_{3}$ were also tested in the Keiser Rig. Reports of these studies are filed with DOE independently.

\section{Additional Studies}

Plasma-sprayed samples of pure $\mathrm{Ta}_{2} \mathrm{O}_{5}$ on AS800 were supplied to J.P. Singh of Argonne National Laboratory for indentation and fracture studies. Dr. Singh's reports his results to DOE under a separate contract. 


\section{CONCLUSIONS AND RECOMMENDATIONS}

The major findings and accomplishments of the work as a result of the cooperative efforts among Northwestern University, Honeywell, Lehigh University and Oak Ride National Laboratory, are as follows:

- Conditions for the plasma spray of $\mathrm{Ta}_{2} \mathrm{O}_{5}$ and its alloys were optimized to provide maximum density (reflecting impermeability) and thickness (reflecting spray efficiency).

- Adherent small particle plasma spray (SPPS) coatings of doped and undoped $\mathrm{Ta}_{2} \mathrm{O}_{5}$ can be routinely prepared.

- $\mathrm{Ta}_{2} \mathrm{O}_{5}$ can be stabilized against its disruptive phase transformation up to temperatures of approximately $1400^{\circ} \mathrm{C}$ by the addition of one or more oxides of $\mathrm{Al}, \mathrm{La}$, and/or $\mathrm{Nb}$.

- Residual stresses, which exist in the $\mathrm{Ta}_{2} \mathrm{O}_{5}$ coatings due to thermal expansion mismatch between coating and substrate, were measured using X-ray techniques and were found to change as a result of thermal exposure.

- Properly doped SPPS coatings are more resistant against thermal cycling than undoped coatings, and properly doped samples can be rapidly thermal cycled many thousand times without coating spallation.

- Water vapor testing in the ORNL Keiser rig of adherent undoped coating, which had not been thermally cycled, showed that undoped $\mathrm{Ta}_{2} \mathrm{O}_{5}$ is not an effective barrier at preventing sub-coating chemical changes to the AS800 substrate. (Reported by ORNL)

- Limited water vapor testing at Honeywell of selectively doped and adherent coatings, which had successfully survived many thermal cycles, showed that in the water vapor environment, de-cohesion may occur.

During the course of this program, the team has shown that $\mathrm{Ta}_{2} \mathrm{O}_{5}$ alloys are capable of being stabilized at all temperatures below $1400^{\circ} \mathrm{C}$, and that certain $\mathrm{Ta}_{2} \mathrm{O}_{5}$ alloys when plasmasprayed using SPPS on AS800 are capable of extended thermal cycling in air without significant delamination. However, from the Keiser rig results and from the Honeywell steam furnace test, it appears that $\mathrm{Ta}_{2} \mathrm{O}_{5}, \mathrm{Ta}_{2} \mathrm{O}_{5}+1.5 \% \mathrm{Al}_{2} \mathrm{O}_{3}$, and $\mathrm{Ta}_{2} \mathrm{O}_{5}+1.5 \% \mathrm{Al}_{2} \mathrm{O}_{3}+1.5 \% \mathrm{La}_{2} \mathrm{O}_{3}$ are not by themselves protective against environmental degradation of the AS800 at coating interface. However, as the thermal expansion of $\mathrm{Ta}_{2} \mathrm{O}_{5}$ is well matched to silicon-based ceramics, $\mathrm{Ta}_{2} \mathrm{O}_{5}$ alloys may be of use as part of a multilayer thermal barrier coating system.

\section{Recommendations for future work}

Future work to find an environmental barrier coating for silicon ceramics based on $\mathrm{Ta}_{2} \mathrm{O}_{5}$ might seek to find other dopants which stabilize $\mathrm{Ta}_{2} \mathrm{O}_{5}$ while providing lower oxide and water vapor transport. Additionally, as the thermal expansion of some $\mathrm{Ta}_{2} \mathrm{O}_{5}$ alloys is well matched to silicon-based ceramics, these alloys may be of use as part of a multilayer thermal barrier coating system. Other candidates for low water vapor transport should be explored. 


\section{Appendix A: Personnel Associated with the Project}

Northwestern University personnel who participated in the effort

Katherine Faber Principal investigator and Professor of Materials Science and Engineering

Chad Franks Undergraduate, senior project (now employed at Boeing)

D. Lynn Johnson Professor Emeritus of Materials Science and Engineering, provided advice regarding statistical design of experiments at no cost to the project

Monica Moldovan Postdoctoral fellow (now employed at Louisiana State University

Christopher Weyant Ph.D. student (now employed at Sandia National Laboratory)

Honeywell personnel who participated in, or who were cognizant of the activities undertaken include the following:
Jim Guiheen
Current Honeywell Project Director
Chien-Wei Li
Previous Honeywell Project Director
Eric Passman
Research engineer involved with powder synthesis
Bjoern Schenk
Honeywell Engines Silicon Nitride technology leader
Derek Raybould
Leader of separately funded Honeywell-internal EBC development effort

Lehigh University personnel who participated in the effort

$\begin{array}{ll}\text { Helen Chan } & \begin{array}{l}\text { Lehigh Project Director and Professor Materials Science and } \\ \text { Engineering }\end{array} \\ \text { Martin Harmer } & \text { Professor of Materials Science and Engineering } \\ \text { Suxing Wu } & \text { Postdoctoral research associate }\end{array}$

Additional personnel who donated time to the project

Jonathan D. Almer Argonne National Laboratory, Advanced Photon Source 


\section{Appendix B: Papers and Presentations}

1. "Tantalum Oxide Coatings as Candidate Environmental Barriers," M. Moldovan, C. M. Weyant, D. L. Johnson and K. T. Faber, J. Thermal Spray Tech. 13 [1] 51-56 (2004).

2. "Residual Stress and Microstructural Evolution in Tantalum Oxide Coatings on Silicon Nitride," C. M. Weyant, K. T. Faber, J. D. Almer, and J. V. Guiheen, to appear in J. Amer. Ceram. Soc., 2005.

3. "Effect of Alumina Additions on Microstructural Aspects of the $\beta$ to $\alpha$ Transformation in Tantalum (V) Oxide," S. Wu, H. M. Chan, and M. P. Harmer, submitted to the J. Am. Ceram. Soc.

4. "Residual Stress and Microstructural Evolution Environmental Barrier Coatings of Tantalum Oxide Alloyed with Alumina and Lanthana," C. M. Weyant, K. T. Faber, J. D. Almer, and J. V.Guiheen, in preparation for J. Amer. Ceram. Soc.

$* * * * * * * *$

5. "Processing of Tantalum Oxide Small Particle Plasma-Sprayed (SPPS) Environmental Barrier Coatings for Use in Gas Turbine Engines," M. Moldovan, C.M. Weyant, and K.T. Faber, Annual Meeting of the American Ceramic Society, St. Louis, MO, April 2002.

6. "Residual Stress Analysis of Small Particle Plasma-Sprayed (SPPS) Tantalum Oxide Environmental Barrier Coatings," C.M. Weyant and K.T. Faber, Annual Meeting of the American Ceramic Society, St. Louis, MO, April 2002.

7. "Effects of Additives on Sintering Behavior of Tantalum Pentoxide," H.M. Chan, M.P. Harmer and S. Wu, Annual Meeting of the American Ceramic Society, St. Louis, MO, April 2002.

8. "Small Particle Plasma Spray Coatings fro Thermal and Environmental Barriers," K.T. Faber, $54^{\text {th }}$ Pacific Coast Regional Meeting and Basic Science Division Meeting, Seattle, WA, September 2002 (invited paper).

9. “Tantalum Oxide-Bases Environmental Barrier Coatings,” J. V. Guiheen, C.-W. Li, H.M. Chan, M.P. Harmer, S. Wu, K. T. Faber, M. Moldovan, C. M. Weyant, M. Ferber and K. More, Environmental Barrier Coatings Workshop, Nashville, TN, November 2002 (invited talk).

10. "Residual Stress Analysis of Plasma Sprayed Tantalum Oxide-Based Environmental Barrier Coatings," C. M. Weyant, K. T. Faber, J. Almer, J. V. Guiheen, Annual Meeting of the American Ceramic Society, Nashville, TN, April 2003

11. "Tantalum Oxide Coatings for Environmental Barriers," K.T. Faber, M. Moldovan and C. Weyant, International Thermal Spray Conference 2003, Orlando, FL, May 2003. 
12. "Phase and Microstructural Evolution in Plasma-Sprayed Tantalum Oxide-Based Environmental Barrier Coatings," C.M. Weyant, K T. Faber, J.V. Guiheen and J.D. Almer, Annual Meeting of the American Ceramic Society, Indianapolis, IN, April 2004.

13. "Tantalum Oxide EBCs for AS800," J. Guiheen, C.-W. Li, H. Chan, M. Harmer, S. Wu, K. Faber, M. Moldovan, C. Weyant, K. More, M. Ferber," Environmental Barrier Coatings Workshop, Nashville, TN, November 2003.

14. "Residual Stresses in Plasma-Sprayed Tantalum Oxide-Based Environmental Barrier Coatings, "C.M. Weyant, K.T. Faber, J.D. Almer, and J.V. Guiheen, Annual Meeting of the American Ceramic Society, Indianapolis, IN, April 2004.

15. “Tantalum Oxide-Based Environmental Barrier Coatings,” K. T. Faber, C. M. Weyant, J. Almer and J.V. Guiheen, $5^{\text {th }}$ International Conference on High-Temperature Ceramic Matrix Composites, Seattle, WA September, 2004. (invited paper) 


\section{Appendix C: Honeywell Thermal Cycling Test Facilities}

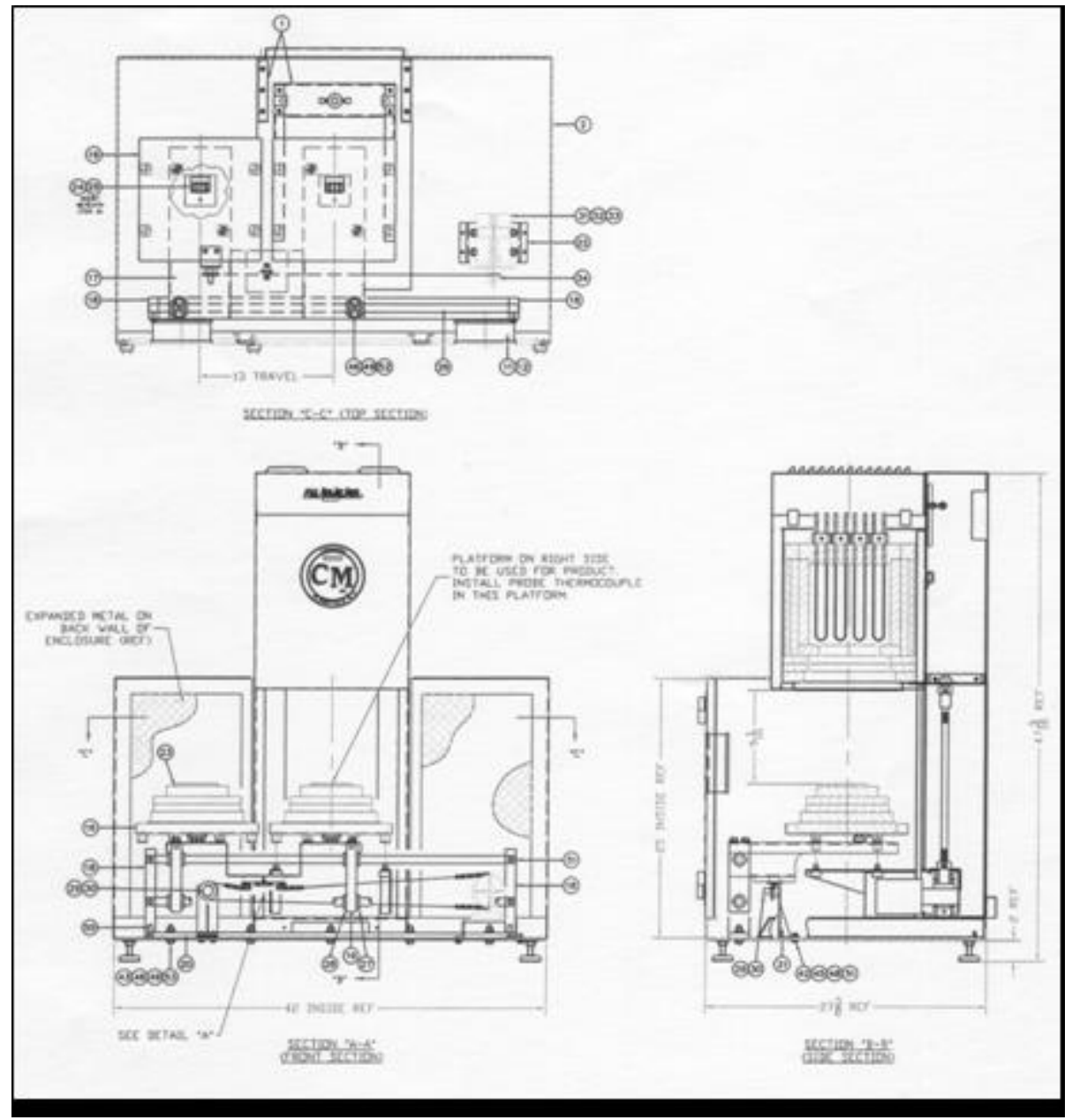

CM Furnaces Model 1708 BL with cycling option

$-\mathrm{T}_{\max }=1700^{\circ} \mathrm{C}$

- Type $\mathrm{B}$ control \& $\mathrm{O} / \mathrm{T}$ thermocouples

- PLC position control and cycle logging

- Extra Monitoring T/C with output to analog chart recorder

- procured under Honeywell funds completely separate from DOE/Northwestern subcontract

- can accommodate samples within a 6" cube

- Room temperature to "at-temp" in 40 seconds

- "at-temp" to fan in 20seconds

- 25 minutes "at temp", 5 minutes off

- Over 2500 cycles logged since February 2003 


\section{Appendix D: Summary log of thermal cycling samples for Round 1}

\begin{tabular}{|c|c|c|c|}
\hline Coating composition & $\begin{array}{l}\text { \#cycles@ } \\
1200^{\circ} \mathrm{C} \\
\end{array}$ & $\begin{array}{l}\text { \#cycles@ } \\
1315^{\circ} \mathrm{C}\end{array}$ & Results, observations \\
\hline \multicolumn{4}{|l|}{ Group X: Uncoated } \\
\hline sample X1 & 139 & & No noticeable visual change \\
\hline sample $\mathrm{X} 2$ & 489 & & No noticeable visual change \\
\hline sample X3 & 986 & & No noticeable visual change \\
\hline sample X4 & 1074 & & No noticeable visual change \\
\hline \multicolumn{4}{|l|}{ Group A: Pure $\mathrm{Ta}_{2} \mathrm{O}_{5}$} \\
\hline sample A1 & 139 & & Delamination seen \\
\hline sample A2 & 489 & & No delamination seen \\
\hline sample A3 & 489 & & No delamination seen \\
\hline sample A4 & 986 & & No delamination seen \\
\hline sample A5 & 1074 & & No delamination seen \\
\hline sample A6 & 1074 & & No delamination seen \\
\hline sample A7: second population & 100 & 1325 & Edges beginning to delam \\
\hline \multicolumn{4}{|l|}{ Group B: $\mathrm{Ta}_{2} \mathrm{O}_{5}+5 \% \mathrm{Al}_{2} \mathrm{O}_{3}$} \\
\hline $\begin{array}{r}\text { sample B1 } \\
\end{array}$ & 139 & & Delaminated \\
\hline sample B2 & 489 & & Delaminated \\
\hline sample B3 & 489 & & Delaminated \\
\hline sample B4 & 986 & & Delaminated \\
\hline sample B5 & 1074 & & Delaminated \\
\hline sample B6 & 1074 & & Delaminated \\
\hline sample B7 & 1074 & & Delaminated \\
\hline \multicolumn{4}{|l|}{ Group C: $\mathrm{Ta}_{2} \mathrm{O}_{5}+2 \% \mathrm{Al}_{2} \mathrm{O}_{3}$} \\
\hline sample C1 & 145 & & No delamination seen \\
\hline sample C2 & 489 & 2033 & $\begin{array}{l}\text { No delamination seen at } 1500 \text { cycles. } \\
\text { Delamination noted at } 1700 \text { cycles }\end{array}$ \\
\hline sample C3: second population & 100 & 1325 & $\begin{array}{l}\text { No delam. seen by Guiheen. Severe } \\
\text { edge delam. seen by Weyant }\end{array}$ \\
\hline \multicolumn{4}{|l|}{$\begin{array}{l}\text { Group D: } \mathrm{Ta}_{2} \mathrm{O}_{5}+3 \% \mathrm{Al}_{2} \mathrm{O}_{3}+ \\
3 \% \mathrm{La}_{2} \mathrm{O}_{3}\end{array}$} \\
\hline sample D1 & 145 & & No delamination seen \\
\hline sample D2 & 489 & & No delamination seen \\
\hline sample D3: second population & 100 & 3358 & No delamination seen \\
\hline \multicolumn{4}{|l|}{ Group E: $\mathrm{Ta}_{2} \mathrm{O}_{5}+3 \% \mathrm{Al}_{2} \mathrm{O}_{3}$} \\
\hline sample E1 & 100 & 3358 & $\begin{array}{l}\text { No delam. seen at } 2825 \text { cycles. } \\
\text { Delamination at } 3025 \text { cycles }\end{array}$ \\
\hline
\end{tabular}


Appendix E: Summary log of thermal cycling samples for $2^{\text {nd }}$ group of samples

\begin{tabular}{|c|c|c|}
\hline Coating composition & $\begin{array}{l}\text { \#cycles@ } \\
1200^{\circ} \mathrm{C}\end{array}$ & Results, observations \\
\hline \multicolumn{3}{|l|}{ Group $\mathrm{A}^{\prime}: \mathrm{Ta}_{2} \mathrm{O}_{5}+1.5 \mathrm{wt} \% \mathrm{Al}_{2} \mathrm{O}_{3}$} \\
\hline sample A'1 & 140 & No delamination seen \\
\hline sample A'2 & 490 & No delamination seen \\
\hline sample A'3 & 1080 & No delamination seen \\
\hline \multicolumn{3}{|l|}{ Group B': $\mathrm{Ta}_{2} \mathrm{O}_{5}+1.5 \mathrm{wt} \% \mathrm{Al}_{2} \mathrm{O}_{3}$} \\
\hline sample B'1 & 140 & No delamination seen \\
\hline sample B'2 & 490 & No delamination seen \\
\hline sample B'3 & 1080 & No delamination seen \\
\hline \multicolumn{3}{|l|}{$\begin{array}{l}\text { Group C': } \mathrm{Ta}_{2} \mathrm{O}_{5}+1.5 \mathrm{wt} \% \mathrm{Al}_{2} \mathrm{O}_{3}+1.5 \% \\
\mathrm{La}_{2} \mathrm{O}_{3}\end{array}$} \\
\hline sample C'1 & 140 & No delamination seen \\
\hline sample C'2 & 490 & No delamination seen \\
\hline sample C’3 & 1080 & No delamination seen \\
\hline \multicolumn{3}{|l|}{$\begin{array}{l}\text { Group D': } \mathrm{Ta}_{2} \mathrm{O}_{5}+1.5 \mathrm{wt} \% \mathrm{Al}_{2} \mathrm{O}_{3}+1.5 \% \\
\mathrm{La}_{2} \mathrm{O}_{3}\end{array}$} \\
\hline sample D'1 & 140 & No delamination seen \\
\hline sample D’2 & 490 & No delamination seen \\
\hline sample D’3 & 1080 & No delamination seen \\
\hline \multicolumn{3}{|l|}{ Group E': $\mathrm{Ta}_{2} \mathrm{O}_{5}+1.5 \mathrm{wt} \% \mathrm{Al}_{2} \mathrm{O}_{3}$} \\
\hline sample E'1 & 140 & No delamination seen \\
\hline sample E'2 & 490 & No delamination seen \\
\hline \multicolumn{3}{|l|}{ Group E': $\mathrm{Ta}_{2} \mathrm{O}_{5}+1.5 \mathrm{wt} \% \mathrm{Al}_{2} \mathrm{O}_{3}$} \\
\hline sample F'1 & 140 & No delamination seen \\
\hline sample F'2 & 490 & No delamination seen \\
\hline
\end{tabular}

